Article

\title{
Post-Earthquake Damage Assessment-Case Study of the Educational Building after the Zagreb Earthquake
}

\author{
Luka Lulić, Karlo Ožić, Tomislav Kišiček (D), Ivan Hafner (D) and Mislav Stepinac *D \\ Faculty of Civil Engineering, University of Zagreb, 10000 Zagreb, Croatia; luka.lulic@grad.unizg.hr (L.L.); \\ karlo.ozic@grad.unizg.hr (K.O.); tomislav.kisicek@grad.unizg.hr (T.K.); ivan.hafner@grad.unizg.hr (I.H.) \\ * Correspondence: mislav.stepinac@grad.unizg.hr
}

Citation: Lulić, L.; Ožić, K.; Kišiček,

T.; Hafner, I.; Stepinac, M.

Post-Earthquake Damage

Assessment-Case Study of the

Educational Building after the Zagreb

Earthquake. Sustainability 2021, 13,

6353. https://doi.org/10.3390/

su13116353

Academic Editor: Giacomo Salvadori

Received: 29 April 2021

Accepted: 27 May 2021

Published: 3 June 2021

Publisher's Note: MDPI stays neutral with regard to jurisdictional claims in published maps and institutional affiliations.

Copyright: (c) 2021 by the authors. Licensee MDPI, Basel, Switzerland. This article is an open access article distributed under the terms and conditions of the Creative Commons Attribution (CC BY) license (https:/ / creativecommons.org/licenses/by/ $4.0 /)$.

\begin{abstract}
In the wake of recent strong earthquakes in Croatia, there is a need for a detailed and more comprehensive post-earthquake damage assessment. Given that masonry structures are highly vulnerable to horizontal actions caused by earthquakes and a majority of the Croatian building stock is made of masonry, this field is particularly important for Croatia. In this paper, a complete assessment of an educational building in Zagreb Lower Town is reported. An extensive program of visual inspection and geometrical surveys has been planned and performed. Additionally, an in situ shear strength test is presented. After extensive fieldwork, collected data and results were input in 3Muri software for structural modeling. Moreover, a non-linear static (pushover) analysis was performed to individuate the possible failure mechanisms and to compare real-life damage to software results.
\end{abstract}

Keywords: assessment; earthquake; Zagreb; case study; cultural heritage

\section{Introduction}

On 22 March 2020, at 6 h 22 min, Zagreb Metropolitan area was hit by an earthquake of medium magnitude $\mathrm{M}_{\mathrm{L}}=5.5$, and intensity of VII, in the epicenter, according to the EMS-98 scale [1]. At $7 \mathrm{~h} 1 \mathrm{~min}$ followed the strongest subsequent earthquake of magnitude $\mathrm{M}_{\mathrm{L}}=5.0$ and intensity of VI. The main earthquake damaged most of the buildings in the Lower Town, including residential buildings, universities, schools, kindergartens, hospitals and public buildings. The vast majority of buildings built after the first mandatory earthquake regulations in former Yugoslavia (1964) [2,3] either remained intact or suffered small damage. Nonetheless, the larger part of the city's historical center (Upper and Lower Town) was severely damaged because the buildings in the center were built before any seismic regulations. The damage to historical buildings is enormous. Numerous museums, churches and university buildings have been severely damaged (Figure 1). At the end of the year, Croatia was hit by another devastating earthquake with an epicenter in Petrinja, located approx. $50 \mathrm{~km}$ from Zagreb $\left(\mathrm{M}_{\mathrm{L}}=6.3\right)$. The quake caused subsequent damage to already damaged buildings, but to a lesser extent.

As well as most parts of the European region, many existing buildings in Croatia are built in masonry. Given that most of the so-called "strategic" buildings of cultural significance and high historical importance are built using masonry, such a condition is suggesting that the assessment and rehabilitation of existing masonry structures must be conducted on a very high level [4-8]. An important part of the structural assessment is numerical analysis. When it comes to existing buildings, a more refined non-linear analysis should be adopted. Non-linear static analysis or pushover analysis is important and is recommended in Eurocode 8-3 as a reference method for such situations. 


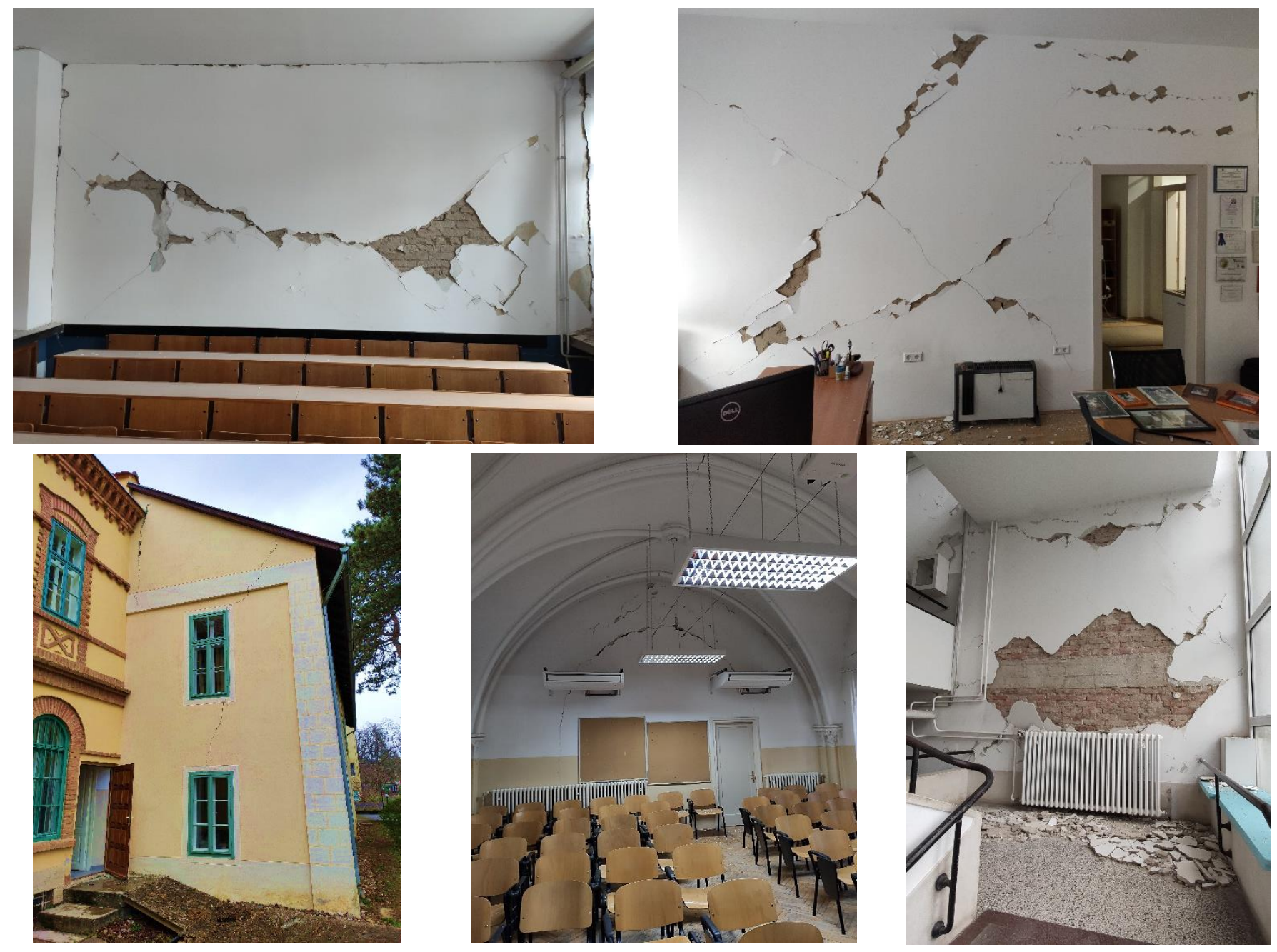

Figure 1. Typical damage to educational buildings after the Zagreb earthquake (photo credit: M. Stepinac).

After the earthquake, the first to respond to a disaster were civil engineers who led and coordinated the entire organization of building assessment and damage detection. Various similar post-earthquake assessment procedures are used worldwide [9-11].

In the first week, a large number of buildings were inspected, with a rapid postearthquake assessment. The most endangered buildings in the city's center were the ones under cultural heritage protection. The aim of a rapid assessment of buildings is to determine the degree of damage to buildings concerning the protection of life and property, that is, to determine if the buildings are usable, temporarily unusable or unusable. Emerging technological advances allow the usage of artificial intelligence in the postearthquake assessment process in the form of machine learning methods for more efficient and precise results $[6,12-15]$.

Zagreb's historic urban complex is a protected area regulated by the Law on the Protection and Preservation of Cultural Heritage. The area is divided into two zones, zone A and zone B (Figure 2) [1]. Zone A includes the oldest and most architecturally valuable parts of Zagreb and is characterized by densely-built blocks of buildings made of stone, brick or a combination of materials. Most buildings consist of massive longitudinal and orthogonal walls and masonry ceiling vaults or wooden ceiling beams and wooden roofs (Figure 3) [1]. Many hospitals, schools, business premises, residential and government buildings, cultural institutions, monuments, churches and chapels are located in zone $A$ and are protected either as part of a historic urban complex or as individual heritage buildings per se. A total of 72\% [1] of buildings in zone A suffered major damage due to the earthquake; to compare the damage suffered by this area is almost proportional to the 
value of its cultural heritage. Zone B consists of a variety of urban patterns and a large number of immensely valuable buildings [16]. According to the World Bank report, in the educational sector, 106 buildings intended for preschool education, 214 primary and secondary school buildings and education centers, and 12 pupils' dorms were damaged. In the higher education subsector, the damage was reported to 152 buildings. In addition, the buildings of 29 research institutes were also affected. The total value of damage and losses to the education sector is estimated at EUR 1.8 billion at pre-disaster prices, with $97.9 \%$ affecting the City of Zagreb [1].

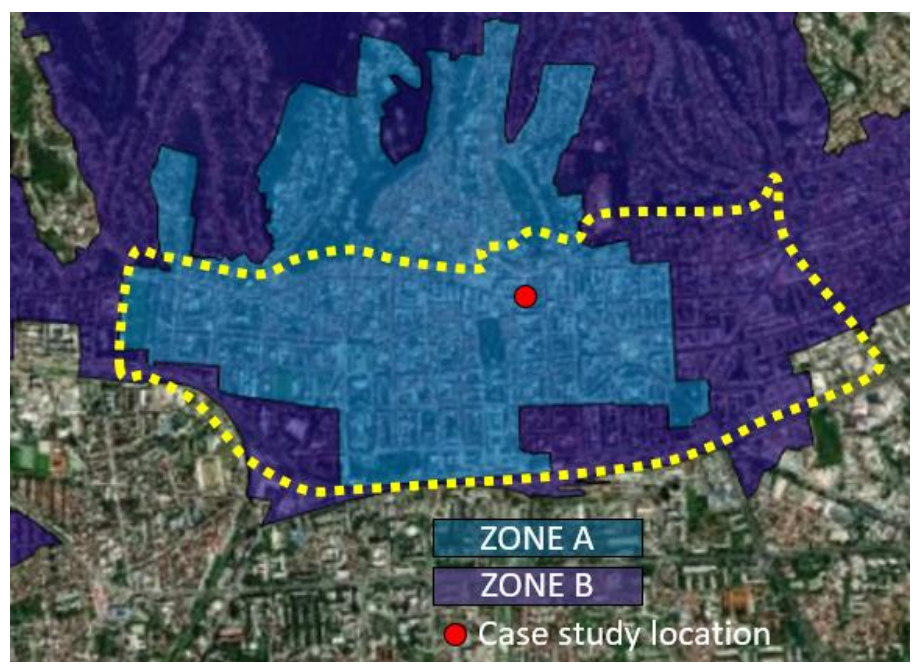

Figure 2. Protected zones A and B with the location of the case study inside the Lower Town of Zagreb (yellow dashed line).
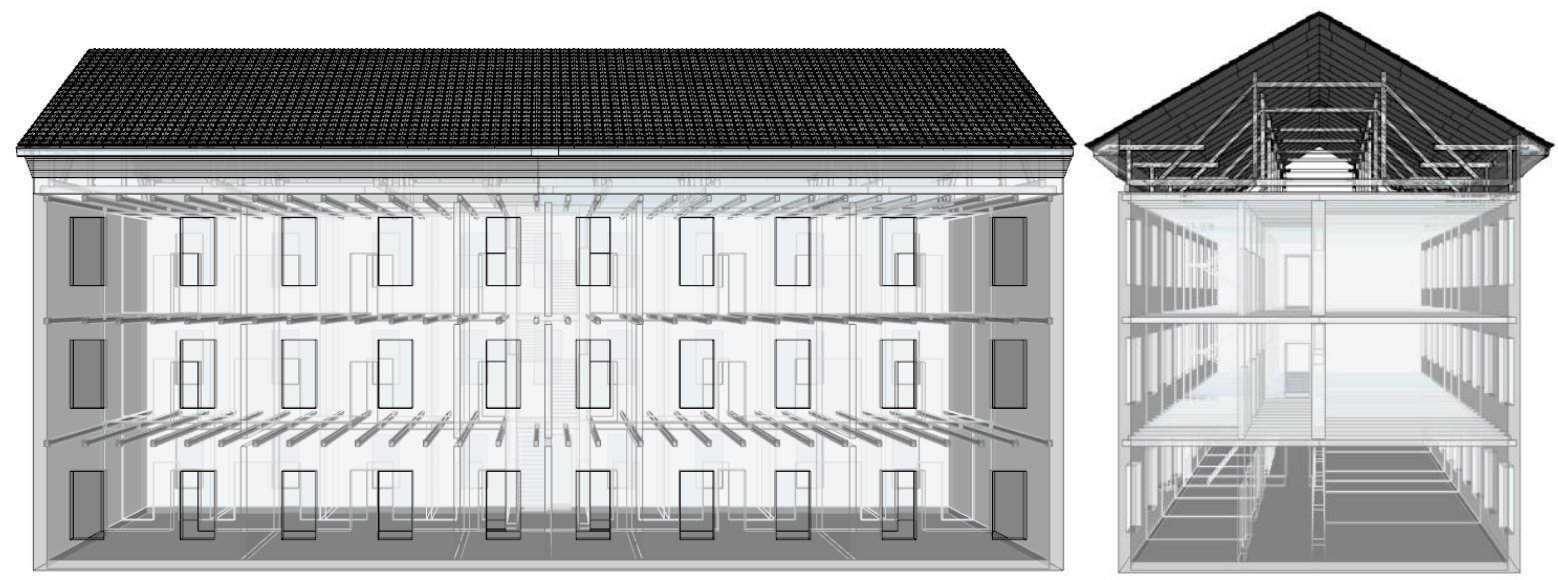

Figure 3. Typical Lower Town masonry building with timber floors and timber roof.

In 2020, there were destructive earthquakes all around the world, causing loss of lives, building collapses, and severe structural and non-structural damage and economic losses (e.g., M7.0 Aegean Sea (Turkey-Greece) [17], M6.7 Elazig (East Turkey) [18], M5.5 and M6.4 Croatia [1]). Identification of vulnerability characteristics and earthquake performance assessment of existing structures are essential steps in reducing earthquake losses, and the topic of seismic assessment of existing masonry structures is actual worldwide. Based on the available state-of-the-art literature on assessment and rehabilitation of existing masonry structures (e.g., [19-23]), this paper presents the Croatian perspective and shows it on an actual case study. 


\section{The Case Study}

The subject of this paper is a building (Figures 4 and 5) located at Vlaška Street 38 as an attached building inside a block. Today's building was built in 1895 by adapting and upgrading two one-story buildings that were built in the early 19th century. The building was upgraded in 1906, while the building's current shape established complete reconstruction in 1997. The building was retrofitted in 1997 for educational purposes and seismic strengthening was not implemented. The building has a rectangular ground plan with the main orientation, which is the longer side of the building in the east-west direction. The building's external dimensions are $12 \times 53 \mathrm{~m}$, with two wings: one, $4.4 \times 7.6 \mathrm{~m}$ and the other, $4.2 \times 5.4 \mathrm{~m}$ located at the south side of the building. The total floor area of the building is approximately $685 \mathrm{~m}^{2}$. The building consists of a basement, first, second, third floor and attic. According to the Croatian seismic hazard map [24], the building is located in the area of peak ground acceleration intensity of $\mathrm{agR}_{\mathrm{gR}}=0.255 \mathrm{~g}$ for a return period of 475 years. The building serves as an educational-scientific institution. The condition of the building before the earthquake, regarding the vertical loads, was satisfactory, and the building was regularly maintained.

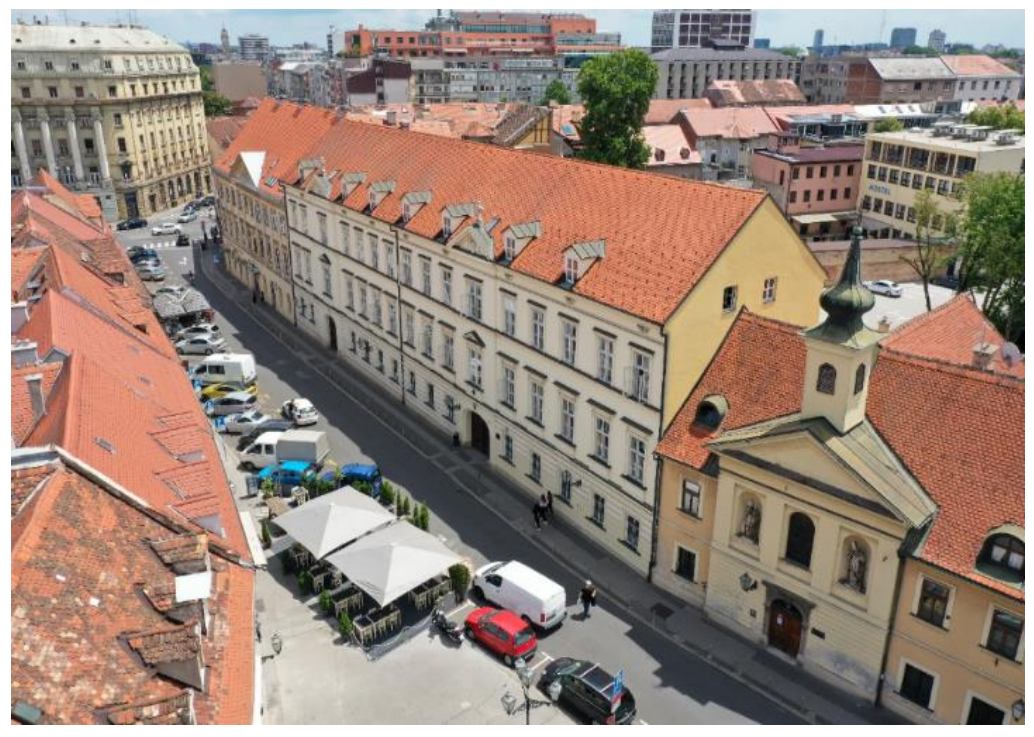

Figure 4. Aerial view of the building—north façade (photo credit: M. Stepinac).

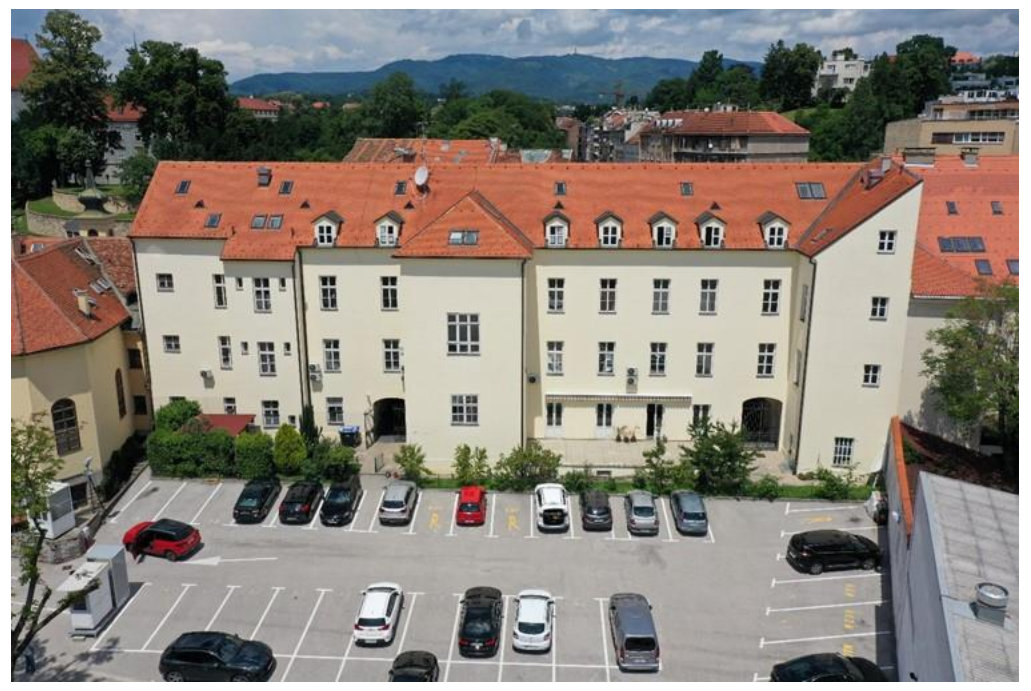

Figure 5. Aerial view of the building—south façade (photo credit: M. Stepinac). 
The original drawings show foundations that are approximately $1.0 \mathrm{~m}$ wide and $1.15 \mathrm{~m}$ deep in relation to the surrounding terrain. They were probably built in brick or stone, which is in line with the construction technology of the time. The building is built of a solid brick of a standard format $30 \times 15 \times 6.5$ (unusual for today's standards) used in the late 19th century. The load-bearing wall thicknesses vary throughout the building, reducing with height, and are 51, 43, $28 \mathrm{~cm}$ (Figures 6 and 7). Plaster thickness also varies throughout the building from 3 to $6 \mathrm{~cm}$. The ceiling structures before the reconstruction in 1997 were wooden beams, except for the basement ceiling and the first floor where the masonry vaults are located. After the 1997 reconstruction, the attic and 2nd floor ceilings (Figures 8 and 9) were replaced with reinforced concrete slabs, $12 \mathrm{~cm}$ and $16 \mathrm{~cm}$, respectively. The 1st floor ceiling is a semi-precast masonry/concrete floor system (Fert ceiling) inserted between the existing wooden beams. In contrast, the ceilings on the ground floor and basement remained masonry vaults. The building also has two auxiliary staircases at the ends of the building made during the 1997 reconstruction and are made of reinforced concrete, and the main central staircase is older and is made of prefabricated stone stairs supported by a wall on one and a beam on the other edge.

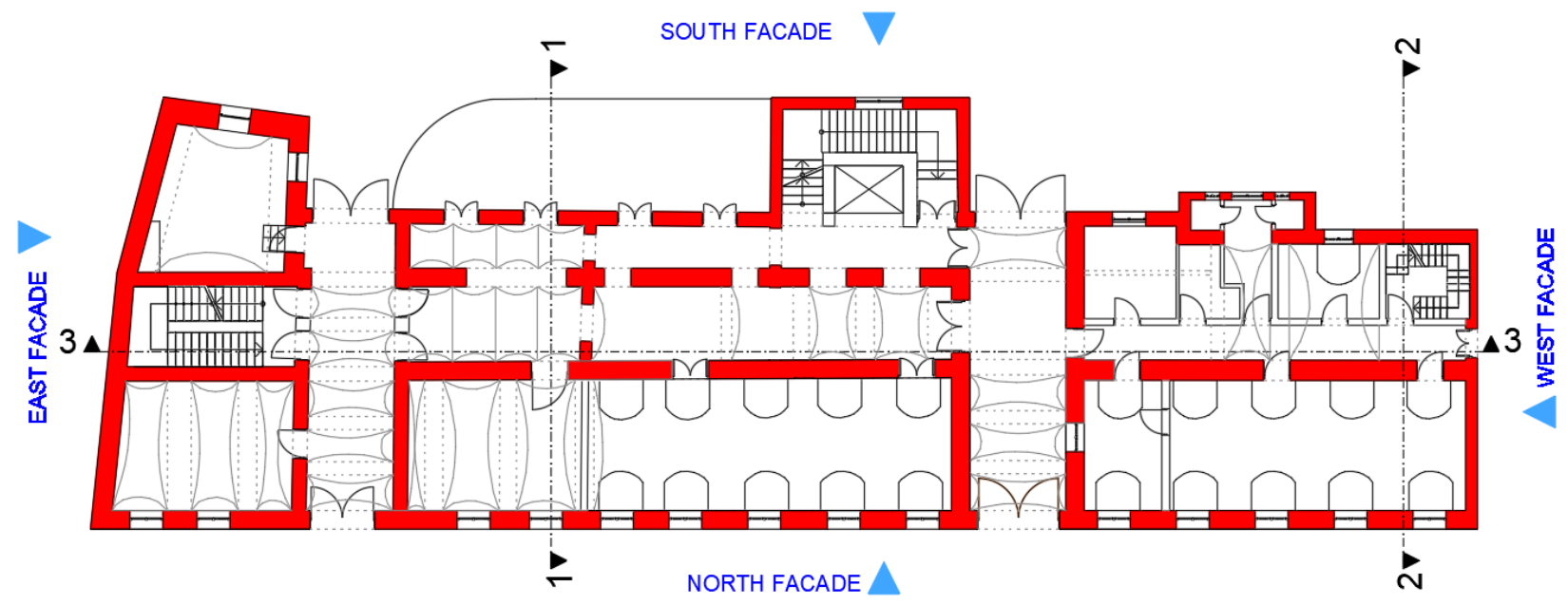

Figure 6. Ground floor plan with load-bearing walls in red.

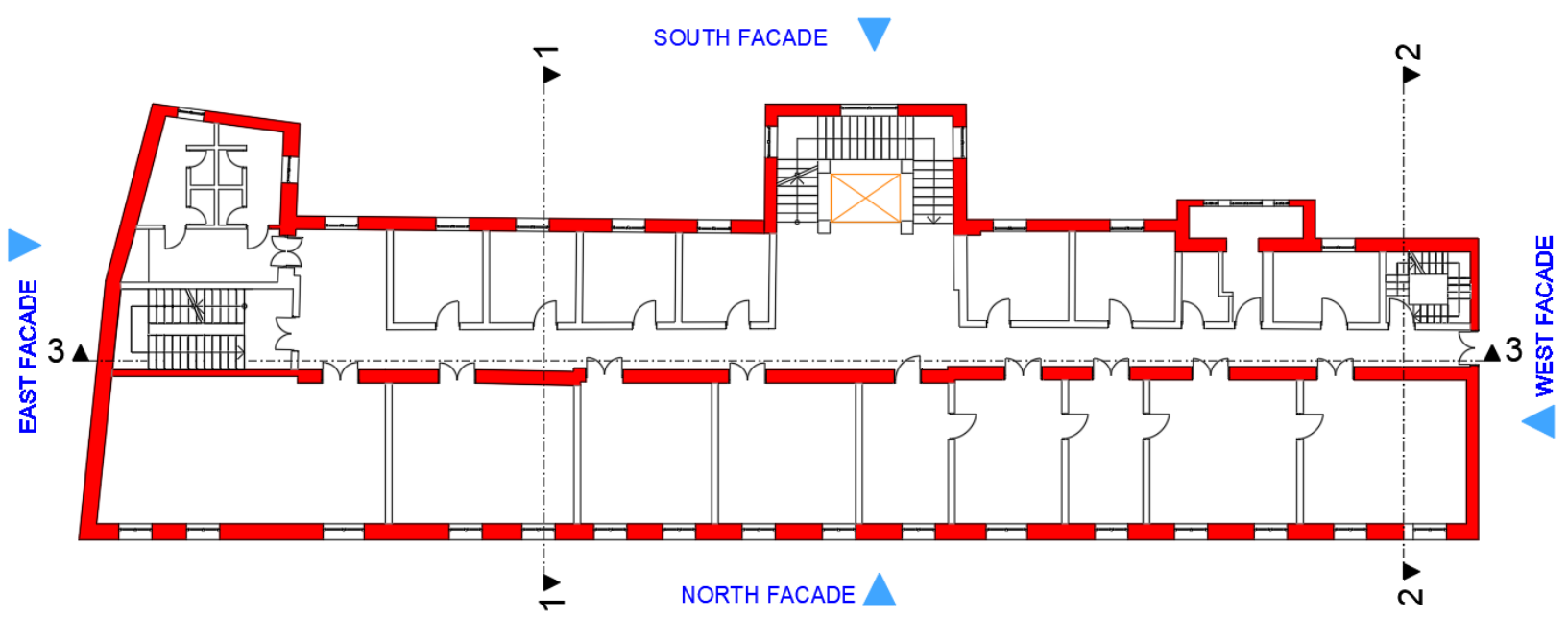

Figure 7. 1st floor plan with load-bearing walls in red. The floor plan of the 2nd floor is identical to the 1st floor plan. 


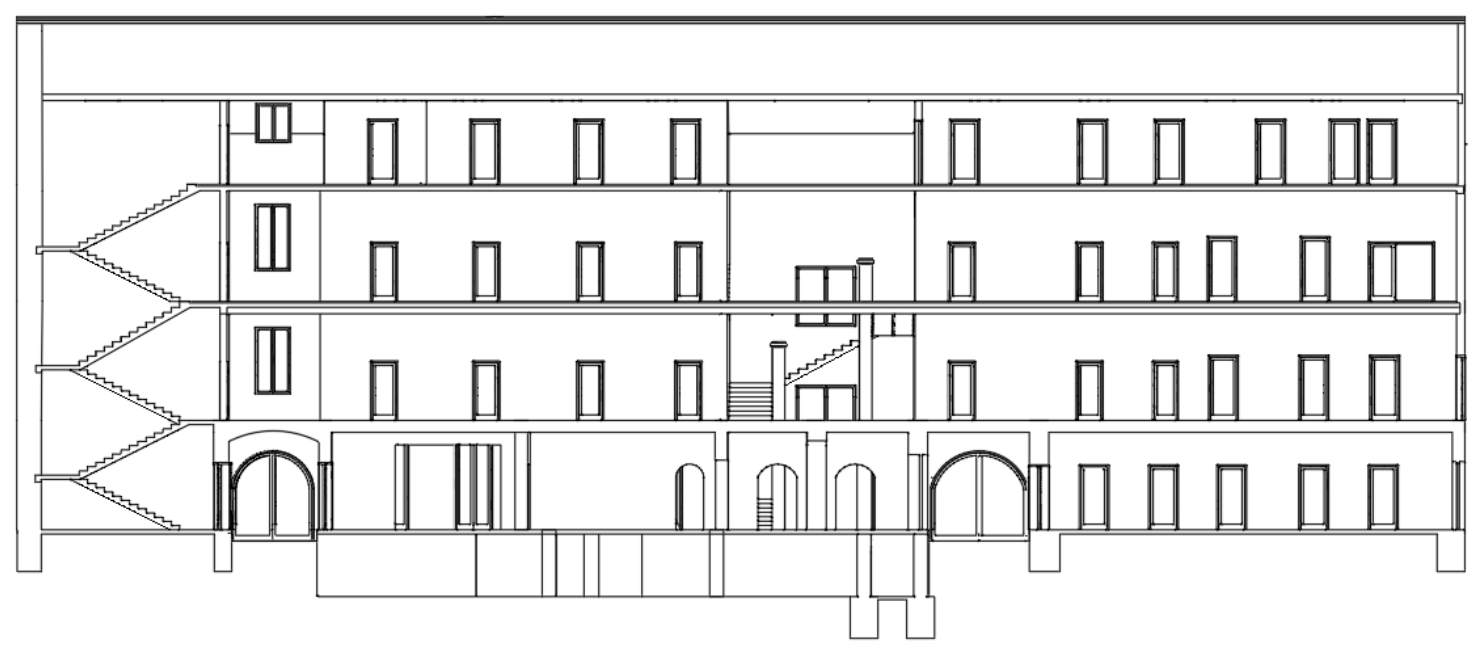

Figure 8. Longitudinal building section.
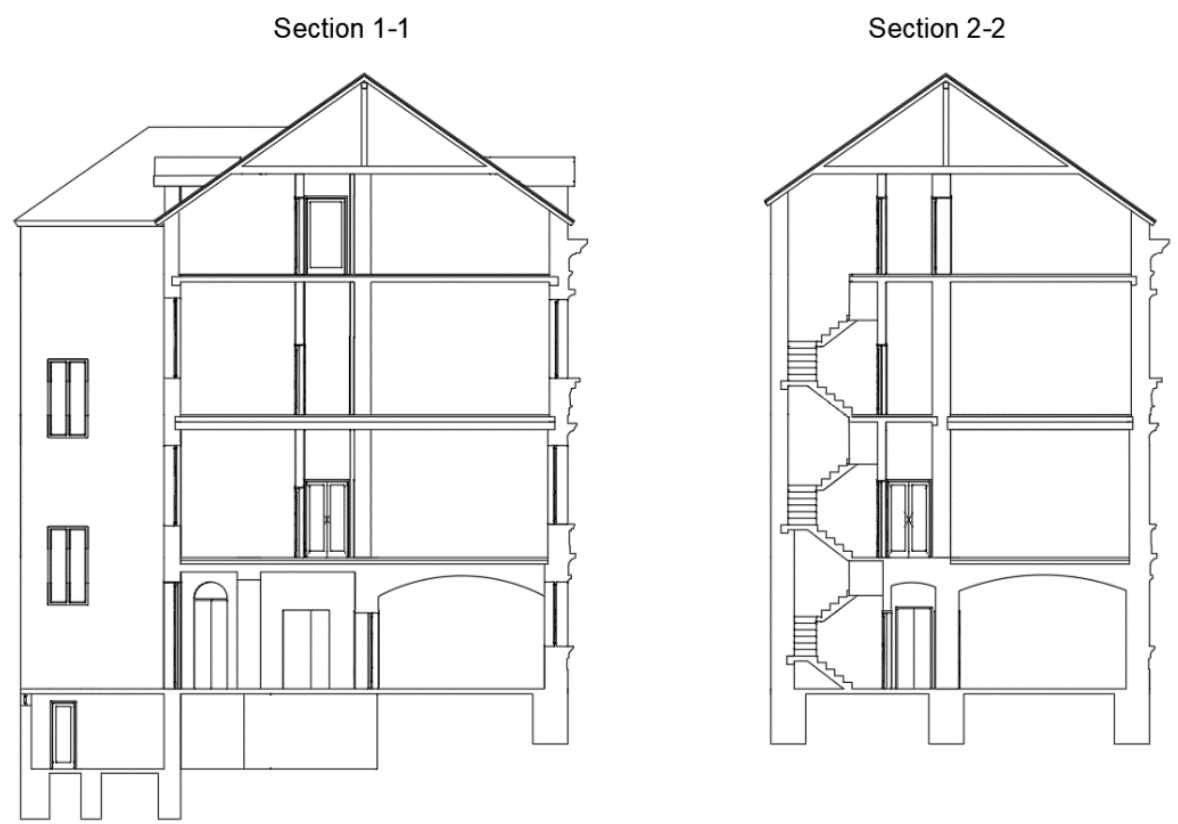

Figure 9. Transversal building sections.

\section{Methodology}

\subsection{Assessment Procedure}

The first step in a complete post-earthquake building assessment is a rapid, preliminary assessment of the usability $[25,26]$ of all buildings damaged in the earthquake. Additionally, it is of great importance to preserve the three-dimensional data of the facades of culturally-protected goods in the form of point clouds obtained by laser scanning or drone imaging. The mentioned data can also be used to assess existing structures for the creation of a 3D numerical model. Similar technology was used in the following papers $[6,27,28]$. In cases where it is needed, detailed assessment and available Non-Destructive Testing (NDT) assessment methods [29] are favorably used. A rapid preliminary assessment is conducted as early as possible after the earthquake, bearing in mind the safety of civil engineers in the field. In Croatia, this type of assessment consisted of a quick visual inspection of individual elements of the load-bearing structure, stating the appropriate degree of damage and deciding on the classification of the building into one of six possible categories (Figure 10): U1 Usable without limitations (Green label), U2 Usable with recommendations 
(Green label), PN1 Temporary unusable—detailed inspection needed (Yellow label), PN2 Temporary unusable - emergency interventions needed (Yellow label), N1 Unusable due to external impacts (Red label) and N2 Unusable due to damage (Red label).
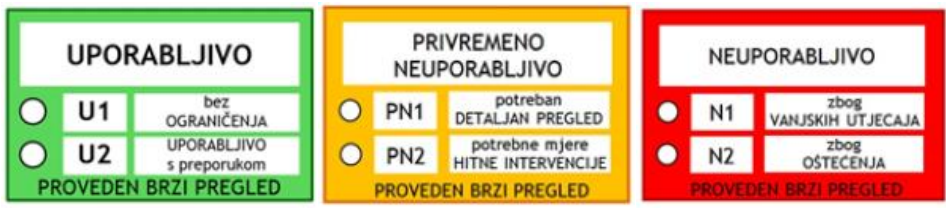

Figure 10. Six categories of usability divided into three original labels (in Croatian) [30].

\subsection{Rapid Preliminary Assessment Results}

A rapid assessment of the building in question was conducted on 23 March 2020. After a quick visual inspection of individual elements of the load-bearing structure, a decision was made to classify the building as temporarily unusable (Yellow label) with a recommendation for a detailed assessment (PN1). Basic conclusions of the preliminary assessment are:

- There is visible damage in the form of cracks on the wall coverings, arches (Figure 11a), vaults and ceilings (Figure 11b) on all floors;

- Separation and local decay of plaster;

- Minor local damage is visible on structural elements (walls, columns, arches);

- In the eastern part of the building, diagonal cracks are visible on the load-bearing walls.

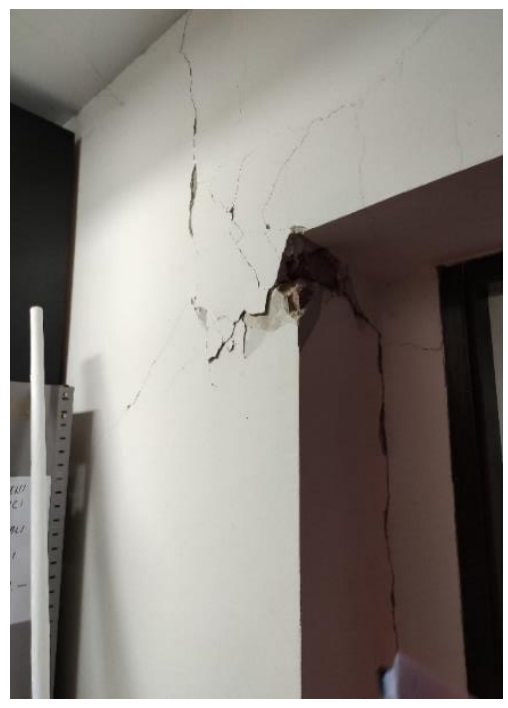

(a)

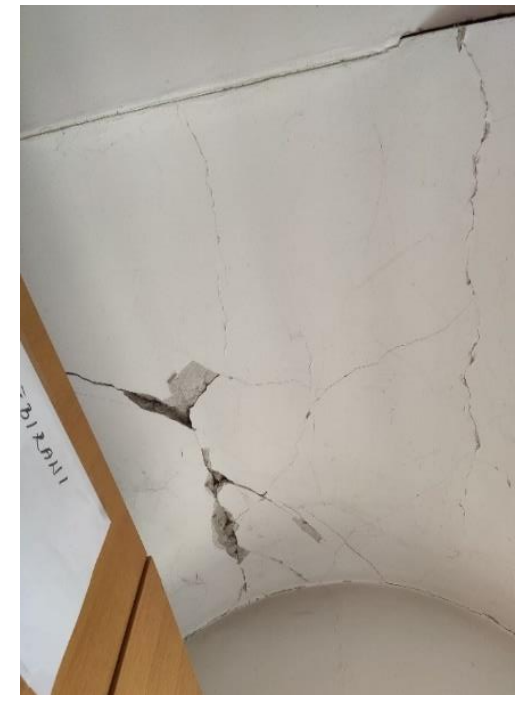

(b)

Figure 11. Cracks on the 1st floor: wall, lintel (a) and ceiling (b) (photo credit: I. Hafner).

The second floor and attic suffered minor damage, while the most severe damage is found on the eastern (Figure 12a,b) and central staircase wings (Figure 13a,b). Recommendations were given that the building can be used with a restriction in the zones where there is a danger of plaster falling. Additionally, the eastern and western staircase can be used with a restriction in the number of people, while the central staircase is not to be used until a detailed assessment is conducted. 


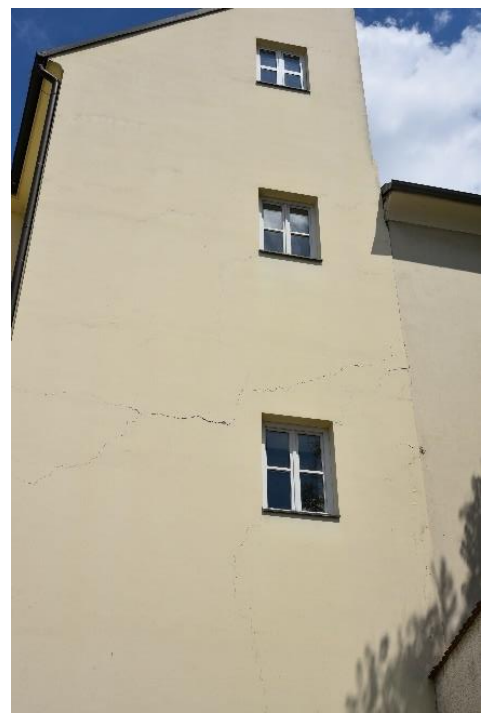

(a)

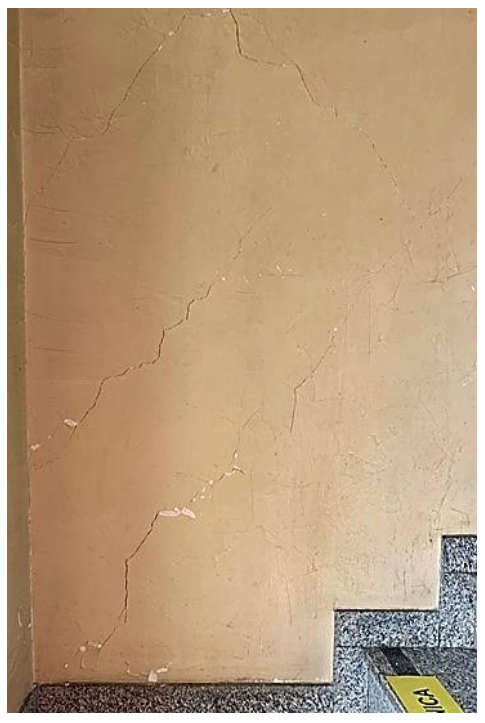

(b)

Figure 12. Cracks on the eastern staircase: exterior (a) and interior (b) (photo credit: I. Hafner).

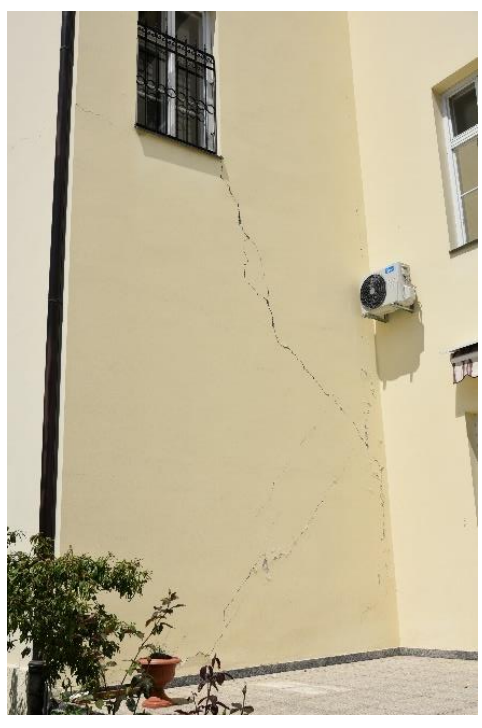

(a)

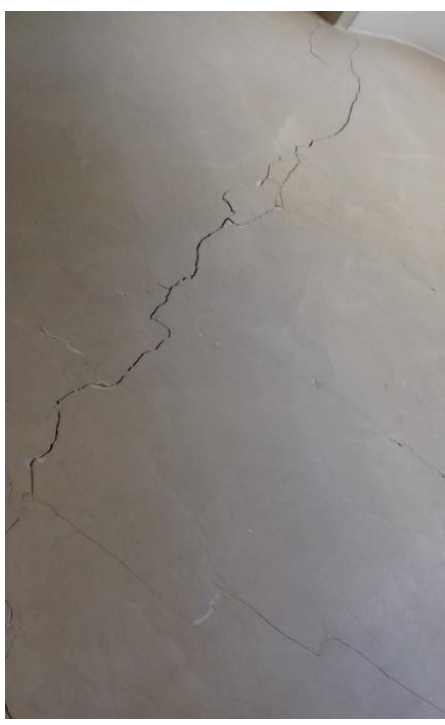

(b)

Figure 13. Diagonal cracks on the central staircase: exterior (a) and interior (b) (photo credit: I. Hafner).

\subsection{Detailed Assessment Results}

According to the current standards for the design of structures-a series of Eurocodes, HRN EN 1990-1998 and the relevant national annexes, the building that is the subject of this study is in the range of peak ground acceleration of $0.255 \mathrm{~g}$; that is, the expected earthquake intensity is IX according to EMS- 98 scale for a return period of 475 years. No geotechnical tests have been performed for the site in question for this article, but based on empirical data, a category B foundation soil (deposits of very compacted sand, gravel or hard clay, at least several tens of meters deep) or category C (deep deposits of compacted or medium-compacted sand, gravel or hard clay with a thickness of several tens of meters to several hundred meters) can be assumed. Moreover, based on the latest findings obtained from the research of the Croatian Geological Institute in cooperation with the University of Zagreb, a seismic microzonation map was prepared according to Eurocode 8 standards for the Zagreb area [31]. According to the mentioned seismic microzonation (2017-2019), the 
soil in the immediate vicinity of the assessed building belongs to the category of soil type C. Soil type $C$ causes a certain amplification of the soil shaking, which must be taken into account when assessing the condition of the structure.

All damage, structural and non-structural, is photographed and described. They are plotted in the floor plans of the building (Figures 14-16). The building was inspected from the air by an unmanned aerial vehicle, and no damage was observed to the main load-bearing structure or the building's roof structure. Decorative crosses, statues and reliefs were also inspected. For the purposes of digital preservation, the 3D model of the building was made on the basis of photogrammetric images.

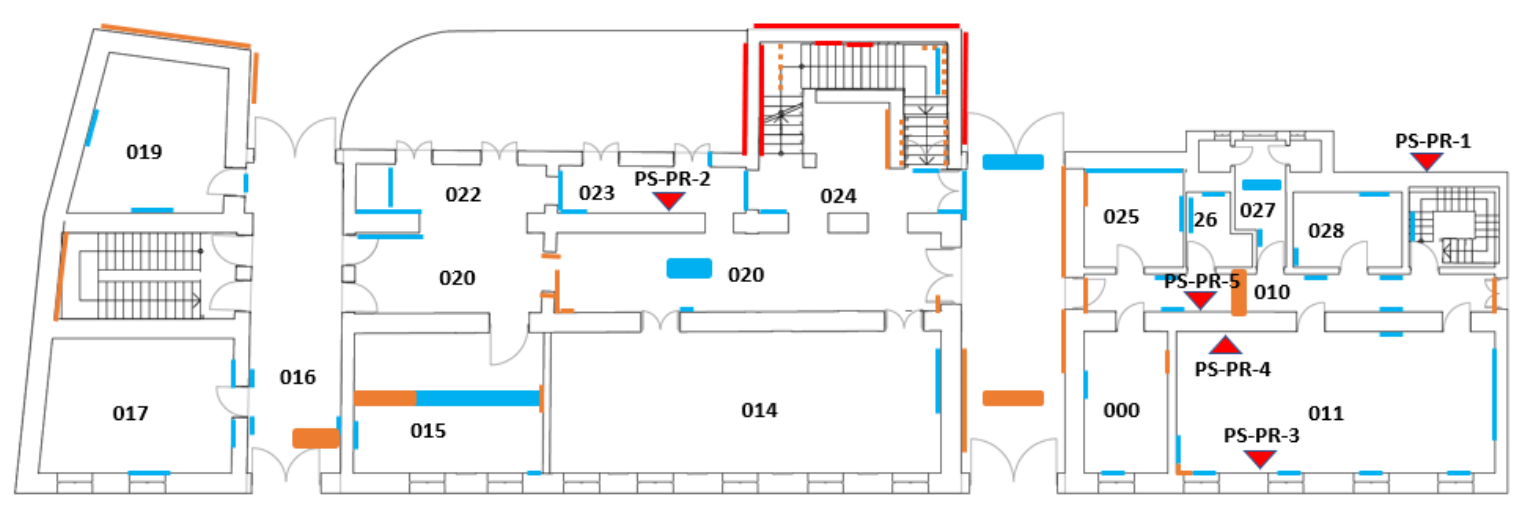

LEGEND $\longrightarrow$ Structural damage-emergency remediation required $\longrightarrow$ Structural damage $\quad$ Non-structural damage

Figure 14. Ground floor of the building-damage scheme and shear strength testing positions.

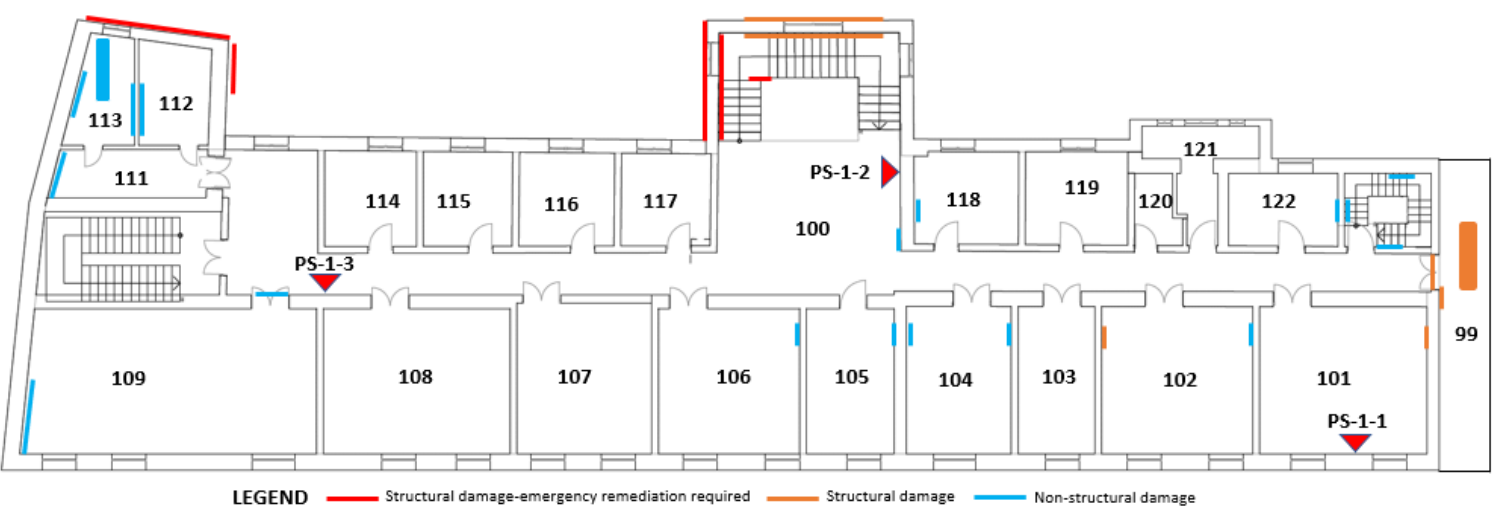

Figure 15. 1st floor of the building-damage scheme and shear strength testing positions.

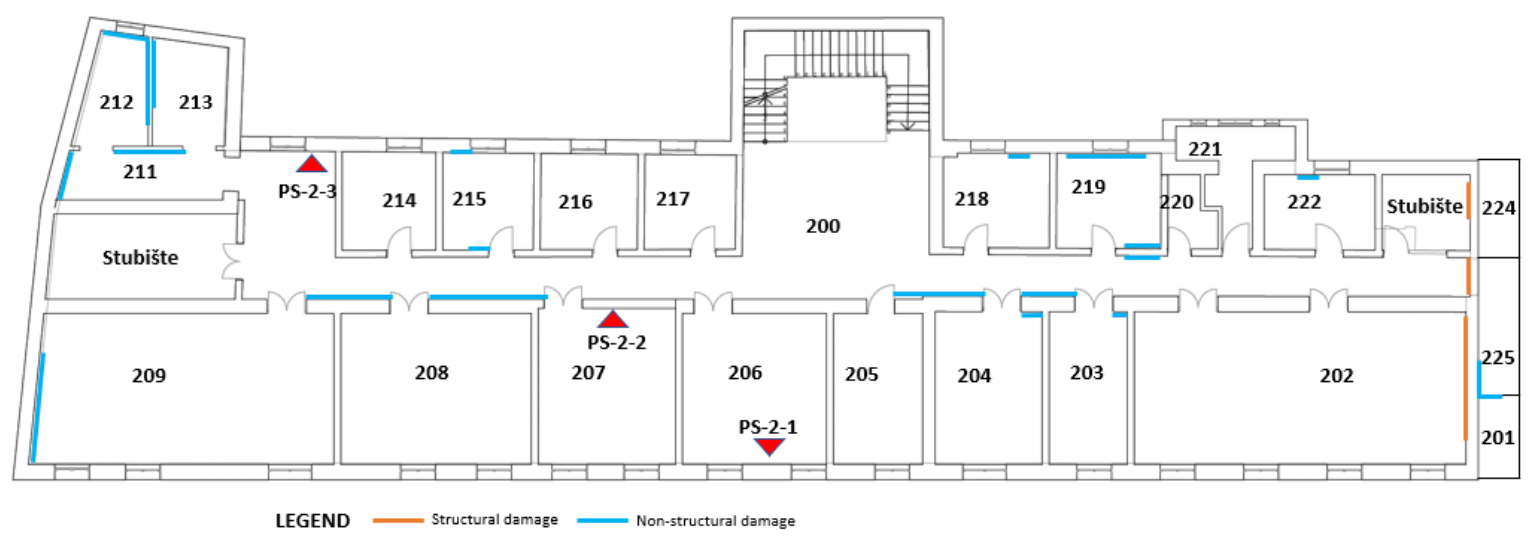

Figure 16. 2nd floor of the building-damage scheme and shear strength testing positions. 
A detailed inspection of the building revealed the following damage: at the ground floor, the damage is visible in the form of cracks on the wall coverings, arches, vaults and ceilings, as well as separation and local decay of plaster. Cracks in the barrel vaults are mostly parallel to the supporting joints, probably due to lateral movements during the earthquake. They are the result of the occurrence of tensile stresses perpendicular to the supporting joint. Such cracks can cause hinge formation and consequent loss of stability if they propagate deep enough. Fortunately, the cracks in the assessed building are narrow and mostly found in the plaster. Minor local damage to structural elements (walls, columns, arches) is also visible. In the central core of the building where the main staircase is located and in the eastern part of the building, diagonal cracks are visible on the load-bearing walls, which can also be seen on the north side of the building. Damage is visible on all floors in the form of cracks and falling plaster on the walls. Minor local damage to the walls on the 1st floor is also visible, and cracks at the joints of partition walls and ceilings are locally visible. In the central wing of the building where the main staircase is located and in the eastern wing of the building, diagonal cracks are visible on the load-bearing walls, which can also be seen on the north side of the building.

The 2nd floor and attic suffered minor damage. Particular attention should be paid to the central part of the building, occupying the wing with the staircase. The formation of cracks on the central wing transverse walls is clearly visible, indicating a possible failure mechanism out-of-plane of the entire wing. A wedge was made, and the cracks were interconnected and propagated inside the building (they also appear in the stair beams). There was no displacement of the walls out-of-plane, but the preconditions for its failure were met. The central wing needs to be strengthened as soon as possible as part of the entire building's renovation.

The east wing was also damaged at the ground floor and 1st floor level. The cracks that appeared propagated were through the entire wall of the south facade of the wing. It is unfavorable that the cracks are joined and continue to the transversely-joined walls and lintels. The cause of such cracks can be the slight contribution of a torsional response of the building as a whole, where the boundary elements are the most loaded ones, and their failure occurs. Additionally, that part with the building is connected to the neighboring building. Although this can generally have a positive effect on the whole building, in the case of walls on the east wing, such a boundary condition can cause additional forces. If the walls are not well connected to the diaphragms by a tensile compression connection, this can cause them to fail. Since there has been no displacement of the wall out-of-plane, it is not in danger of collapsing, but it should be strengthened soon, and further damage propagation should be prevented. Minor damage in the form of cracks on the walls can be seen on the west and east staircases.

The building can be used in its entirety except for the main staircase. Depending on the possibilities in the future, a static and seismic analysis of the existing condition of the building should be made, and regardless of whether the entire building will be reinforced, the main staircase and other walls with cracks along the entire width of the walls must be repaired and reinforced. Before that, it is necessary to do all the research work to determine the characteristics of the masonry and other necessary data for the structural analysis.

\subsection{In Situ Masonry Shear Strength Tests}

In order to assess the condition of the structure after the earthquake and corresponding analysis of the existing condition of the load-bearing structure, in situ tests were carried out. Determination of shear strength (mortar in the composition of load-bearing masonry) of solid brick masonry [32,33] was performed "in situ" using a small hydraulic press "Holmatro" with a load capacity of $200 \mathrm{kN}$. The mortar was moved horizontally in the vicinity of one brick in order to determine the shear strength. At the same time, the structure of the existing wall was minimally damaged. A total of eleven positions on the load-bearing walls were selected for testing the shear strength of the masonry (Figures 14-16): five positions on the ground floor (PS-PR-1 to PS-PR-5), three positions on the 1st floor (PS-1-1 
to PS-1-3) and three positions on the 2nd floor (PS-2-1 to PS-2-3). The shear strength test of the masonry was carried out in nine places. After removing the plaster, it was found that due to the method of masonry (no bricks were found in the longitudinal direction-the inner part of the wall is built of bricks "on edge"), conditions to perform the test were not met for positions PS-PR-3 and PS-PR-4.

\section{Results of the Shear Strength Tests}

The shear strength of the masonry was obtained based on the registered horizontal force $\mathrm{H}_{\text {umax }}$ acting on one brick at the time of reaching the shear strength in that brick and the corresponding mortar area on both sides of the shear is transmitted $(\mathrm{Ag}+\mathrm{Ad})$. The test method can be seen in Figure 17 and photographs (Figures 18 and 19).

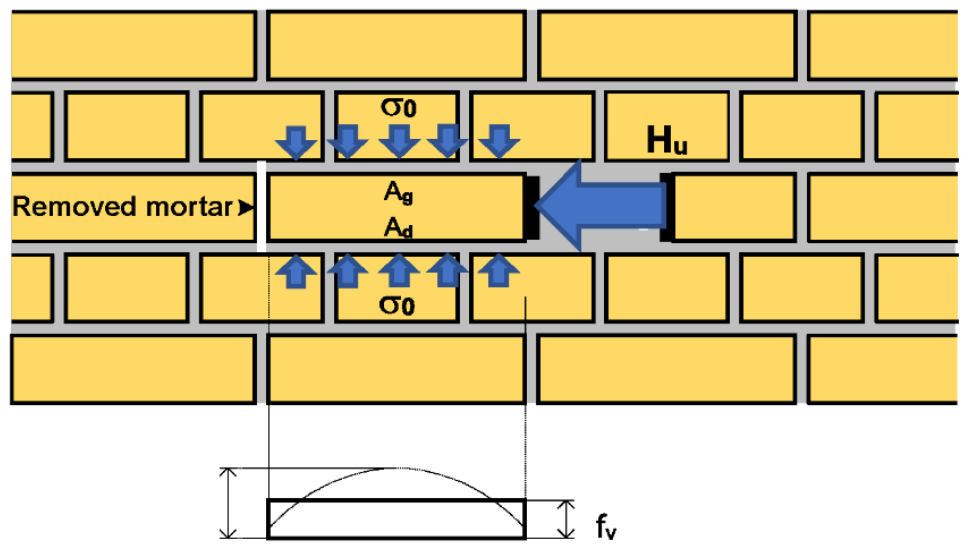

Figure 17. Masonry shear strength test method.

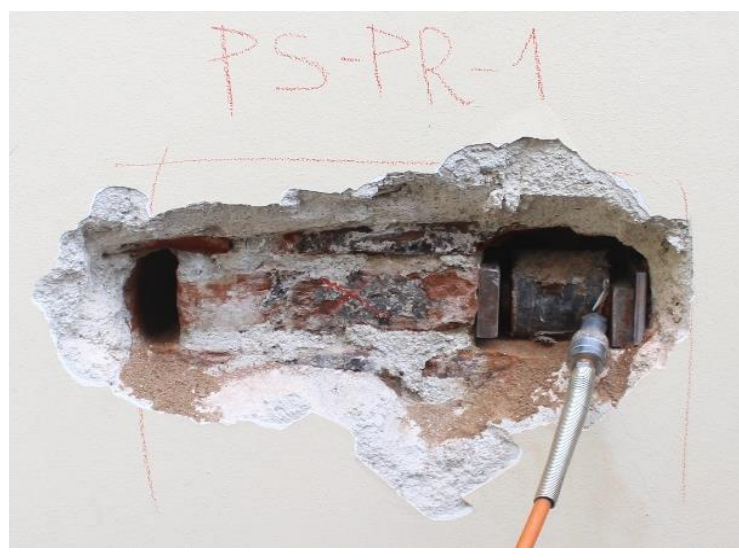

(a)

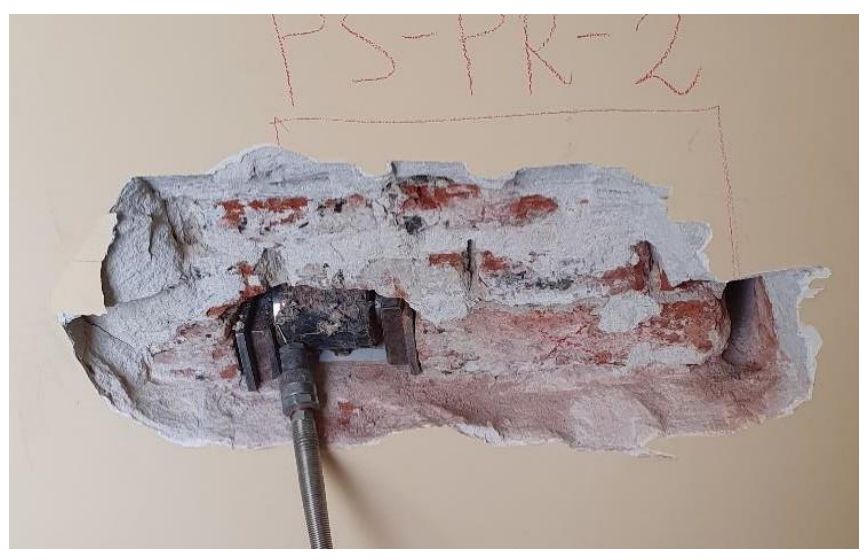

(b)

Figure 18. Masonry shear strength tests at measuring positions PS-PR-1 (a) and PS-PR-2 (b) on the ground floor (photo credit: L. Lulić). 


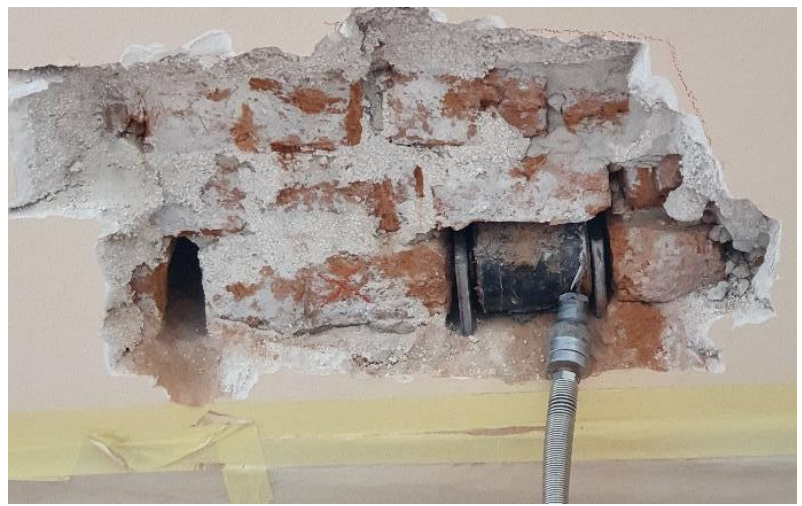

(a)

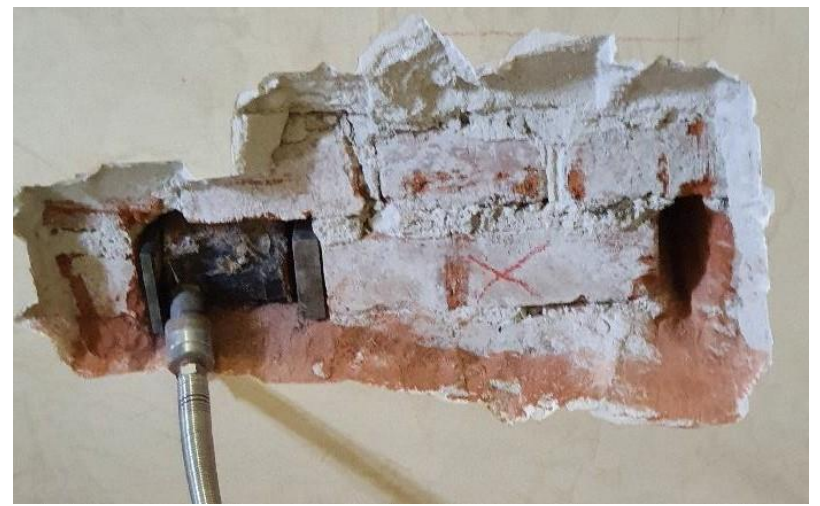

(b)

Figure 19. Masonry shear strength tests at measuring positions PS-1-1 (a) and PS-1-3 (b) on the 1st floor (photo credit: L. Lulić).

The masonry shear strength test results in the load-bearing walls of the ground floor, 1 st floor and 2 nd floor are shown in the following Table 1 . The values from testing site positions PS-PR-5, PS-1-1, PS-1-2 and PS-2-3 were disregarded because of significant deviations from other results (Figure 20).

Table 1. Masonry shear strength test results in load-bearing walls.

\begin{tabular}{cccccc}
\hline Floor & Testing Site & $\mathbf{h} \mathbf{( \mathbf { c m } )}$ & $\mathbf{A}_{\mathbf{h}}\left(\mathbf{c m}^{\mathbf{2}}\right)$ & $\begin{array}{c}\mathbf{H}_{\mathbf{u}, \mathbf{m a x}} \\
\mathbf{( k N )}\end{array}$ & $\begin{array}{c}\text { Shear Strength } \\
\left.\mathbf{f}_{\mathbf{v}} \mathbf{( M P a}\right)\end{array}$ \\
\hline Ground floor & PS-PR-1 & 45 & 784 & 55.5 & 0.708 \\
& PS-PR-2 & 60 & 812 & 58.3 & 0.717 \\
& PS-PR-3 & 75 & - & - & - \\
& PS-PR-4 & 60 & - & - & - \\
& PS-PR-5 & 60 & 504 & 16.3 & 0.323 \\
\hline \multirow{2}{*}{ 1st floor } & PS-1-1 & 50 & 448 & 17.6 & 0.393 \\
& PS-1-2 & 50 & 728 & 121.9 & 1.675 \\
& PS-1-3 & 70 & 526 & 24.4 & 0.464 \\
\hline \multirow{2}{*}{ 2nd floor } & PS-2-1 & 45 & 783 & 44.7 & 0.571 \\
& PS-2-2 & 55 & 812 & 40.6 & 0.500 \\
& PS-2-3 & 55 & 840 & 94.8 & 1.129 \\
\hline
\end{tabular}

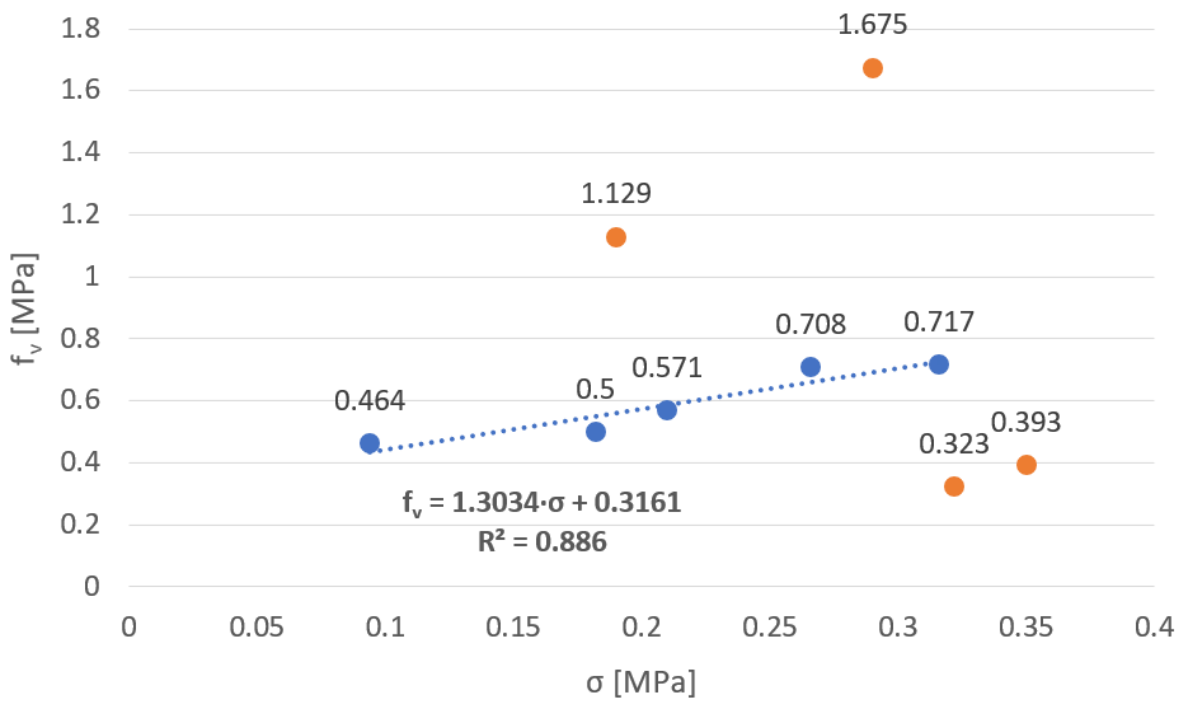

Figure 20. $\mathrm{f}_{\mathrm{v}}$ (shear strength) $-\sigma_{0}$ (vertical stress) diagram. 
It is the shear strength $\mathrm{f}_{\mathrm{V}}$ with the contribution of $\sigma_{0}$-vertical stress. During the test, each measuring position is precisely located to calculate the vertical load $\left(G_{0}\right)$, that is, vertical stress $\left(\sigma_{0}\right)$ from the numerical model. Therefore, for each test site, in addition to the floor plan position, the height of the measuring position from the upper edge of the ceiling structure $(h)$ is recorded. When analyzing the shear strength of mortar, the vertical constant load is taken into account, that is, vertical stresses at a particular test position. Shear strength according to Mohr-Coulomb law is calculated by Equation (1).

$$
\mathrm{f}_{\mathrm{vm}}=\mu \cdot \sigma_{0}+\mathrm{f}_{\mathrm{vm} 0}
$$

It can be seen from the diagram that the shear strength without vertical pressure is $0.316 \mathrm{MPa}$ and that coefficient of friction is 1.303. Due to the high value in comparison to EC standard recommendation, the friction coefficient was taken as $\mu=0.40$ (according to [34]). The obtained shear strength of masonry without vertical pressure, i.e., cohesion, is higher than the one provided by the regulations for the case when there are no tests $\left(f_{\mathrm{vm} 0}=0.32 \mathrm{MPa}>0.10 \mathrm{MPa}\right)$. The results show that the quality of masonry is good in contrast to similar buildings from that period.

\subsection{Numerical Modeling}

The 3D numerical model of the assessed building is obtained in 3Muri software. The macro-element approach is adopted due to computational efficiency and high precision [35]. Its versatility in modeling (implementing elements of various materials, realistic floor stiffnesses, strengthening and many more) makes it highly valuable in a region where a vast majority of building stock is made of masonry. Similar case studies in 3Muri software were used as a base for our research [36-38].

Macro-element approach implies equivalent-frame method which uses non-linear beam elements. Macro-elements (or non-linear beam elements) are divided into three categories which are piers, spandrels and rigid nodes. In piers and spandrels, all deformation is concentrated, and they are connected with rigid nodes. Figure 21 shows an equivalent frame model made of mentioned macro-elements.
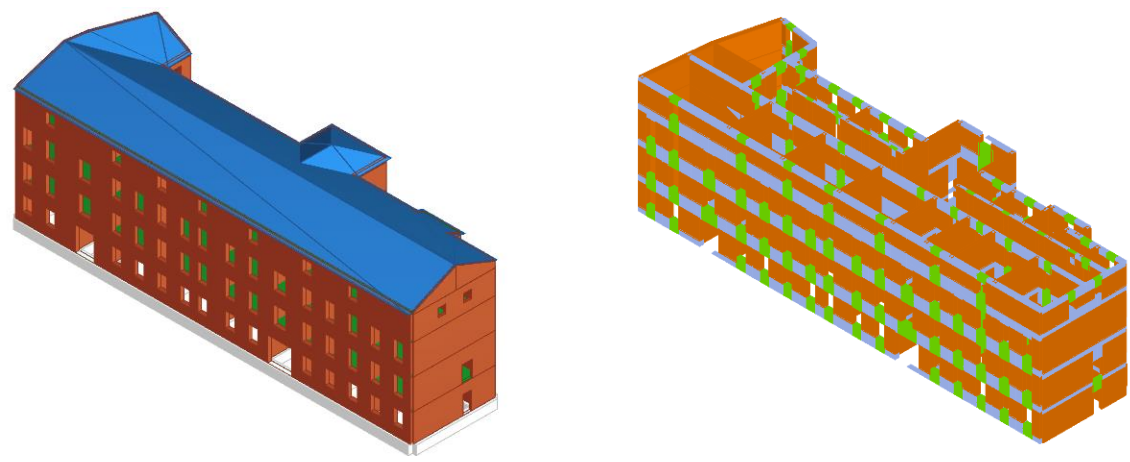

Figure 21. 3D model and 3D equivalent frame in 3Muri.

Non-linear static pushover analysis $[39,40]$ allows us to check the overstrength ratio used in linear analysis and it gives us more detailed insight into critical elements, possible failure mechanisms, and global behavior of the building as a whole. Pushover analysis is performed with constant gravity loads and monotonically-increasing horizontal loads. Two different distributions of the horizontal loads along the structure's height are used for the pushover analysis. The first distribution has a uniform pattern where the horizontal load is proportional to the mass of the building. The second distribution has a modal pattern where the horizontal load is distributed along with the building's height proportionally to the first vibration mode shape of the building determined through elastic analysis (Figures 22 and 23). These horizontal loads are applied at the location of the masses in the model, i.e., at each floor level in the center of masses. Moreover, accidental eccentricity is taken into account to cover uncertainty in the calculation of the center of masses of the 
building. The $5 \%$ of the building's length perpendicular to seismic load direction is taken into account on each side for both $\mathrm{x}$ (longitudinal) and $\mathrm{y}$ (transverse) directions.

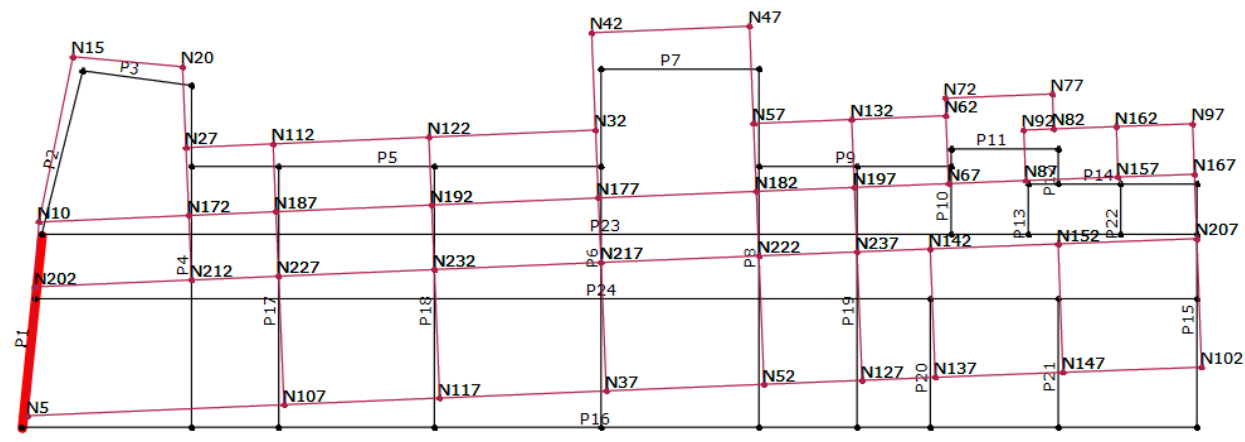

Figure 22. Mode shape used for pushover in $\mathrm{y}$-direction, $\mathrm{T}=0.37 \mathrm{~s}$.

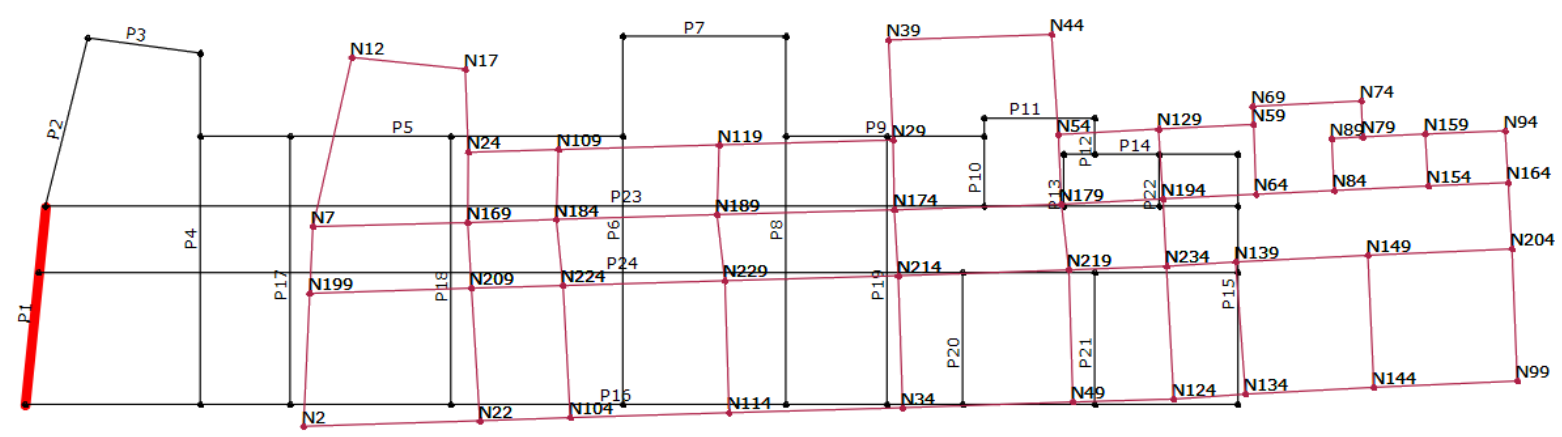

Figure 23. Mode shape used for pushover in $\mathrm{x}$-direction, $\mathrm{T}=0.24 \mathrm{~s}$.

In each incremental step, internal forces are redistributed according to the element equilibrium, and stiffness is degraded in plastic range. Additionally, ductility is controlled with maximum drift which is 0.004 for shear failure and 0.008 for bending failure [34,41]. Generally, masonry walls have three main failure modes as described in [41-44]. TurnsekCacovic constitutive law is used as diagonal cracking is usually the dominant failure mode for existing unreinforced masonry structures $[45,46]$. In the work of [47], diagonal failure strength is correlated with shear strength used for Turnsek-Cacovic constitutive law. Shear strength obtained by in situ testing is compared with shear strength approximation from the visual MQI method which is explained in more detail in [48] and further developed in $[49,50]$. Compared shear strengths are very close for this case study which implies good precision of the MQI method. Cracked stiffness of vertical elements is used in a model as recommended in [34], so that cracking that occurs during lifetime because of expected earthquakes of a smaller magnitude is taken into account. Shear and flexural stiffness are taken as half value of initial stiffness.

In a 3D model, floors are modeled as horizontally rigid diaphragms, which is precise enough due to the real in-plane stiffness of the horizontal floor structures. Axial in-plane stiffness of rigid diaphragms in software is infinite and the mass of the real slab is taken into account. Many similar old masonry buildings have an unfavorable distribution of seismic forces due to traditional flexible timber floors [22]. In seismic analysis, the roof is excluded from the load-bearing structure because it does not significantly affect the response of the structure and does not contribute to the global resistance of the structure. Although it was left out of the structural part, its contribution in the form of load on the structure itself was not neglected.

The mean values of material characteristics used in the numerical model (Table 2) are a combination of the literature review $[34,51]$ and on-site testing. Regarding experimental in situ tests and detailed inspection of the structure knowledge level 2 (normal knowledge) can be defined. Based on the achieved knowledge level, confidence factor was taken as 1.2. 
Table 2. Masonry material characteristics.

\begin{tabular}{cc}
\hline Material Characteristic & Value \\
\hline Modulus of elasticity & $3000 \mathrm{~N} / \mathrm{mm}^{2}$ \\
Shear modulus & $1200 \mathrm{~N} / \mathrm{mm}^{2}$ \\
Specific weight & $18 \mathrm{kN} / \mathrm{m}^{3}$ \\
Shean compressive strength of masonry & $6.63 \mathrm{~N} / \mathrm{mm}^{2}$ \\
Shear strength & $0.14 \mathrm{~N} / \mathrm{mm}^{2}$ \\
Characteristic compressive strength of masonry & $5.53 \mathrm{~N} / \mathrm{mm}^{2}$ \\
Confidence factor & 1.2 \\
Partial safety factor for material & 1 \\
Shear drift & 0.0053 \\
Bending drift & 0.0107 \\
Final creep coefficient & 0.5 \\
\hline
\end{tabular}

According to the work in [52], the building is classified as regular in height but irregular in floor plan, requiring 3D modeling. The building is classified as a torsional stiff system.

First, static analysis is performed according to [53]. Next, the seismic analysis is done. The educational building belongs to importance class III because its seismic resistance is of great importance given the consequences associated with a collapse. Hence, importance factor is $\gamma_{\mathrm{I}}=1.2$. Three PGA values are used for two limit states. According to the new law "Law on the Reconstruction of Earthquake-Damaged Buildings in the City of Zagreb, Krapina-Zagorje County and Zagreb County (NN 102/2020)" [54], ultimate limit state return period can be different depending on the level of strengthening for old masonry buildings damaged in the recent earthquakes. Limit state of significant damage with a return period of 475 and limit state of damage limitation with a return period of 95 years were checked [55]. In the new law [54], the return period of 225 years which corresponds to a probability of exceedance of $20 \%$ in 50 years is introduced for a limit state of significant damage.

Elastic response spectrums for acceleration are calculated for all three return periods taking into account parameters for soil type $\mathrm{C}$, which is found on the location of the building. Altogether, 24 pushover analyses are performed; for $\mathrm{x}$ - and $\mathrm{y}$-direction in both orientation, with two load distributions, without and with $-/+5 \%$ of accidental eccentricity.

The result of the performed seismic analysis is a capacity curve that shows the ratio of the shear force in the base of the structure and the displacement of the control node. The control node was selected in the immediate vicinity of the center of mass and is located on the top floor of the building. Obtained capacity curves for all 24 analyses can be seen in Figure 24. Bilinearized pushover curves for the $x$ - and y-direction are shown in Figures 25 and 26. Total base shear in $\mathrm{kN}$ is plotted on the $\mathrm{y}$-axis and the displacement of the control nodes in $\mathrm{mm}$ is plotted on the $\mathrm{x}$-axis.

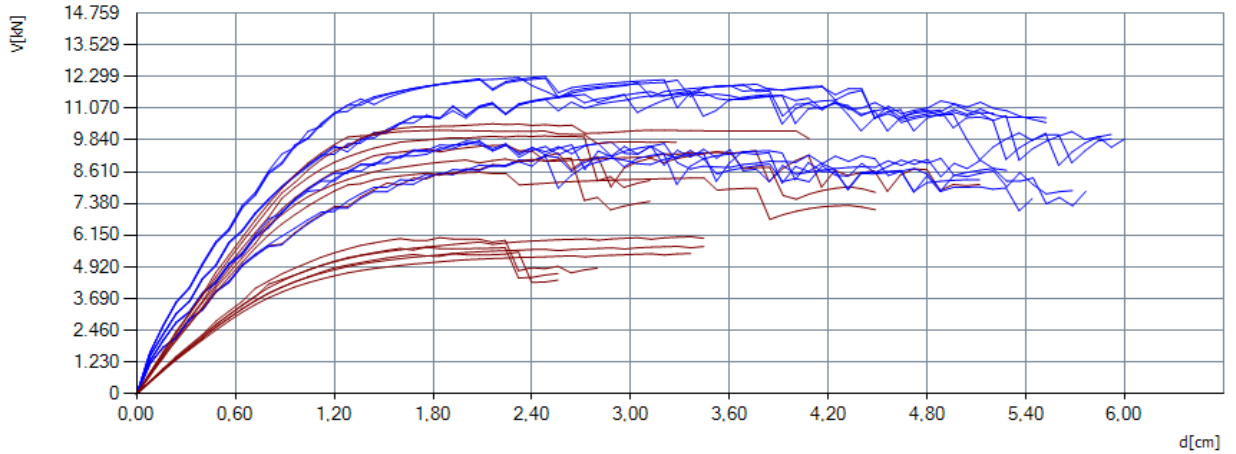

Figure 24. Pushover curves for the $\mathrm{x}$ - (blue) and $\mathrm{y}$ - (red) direction. 
产

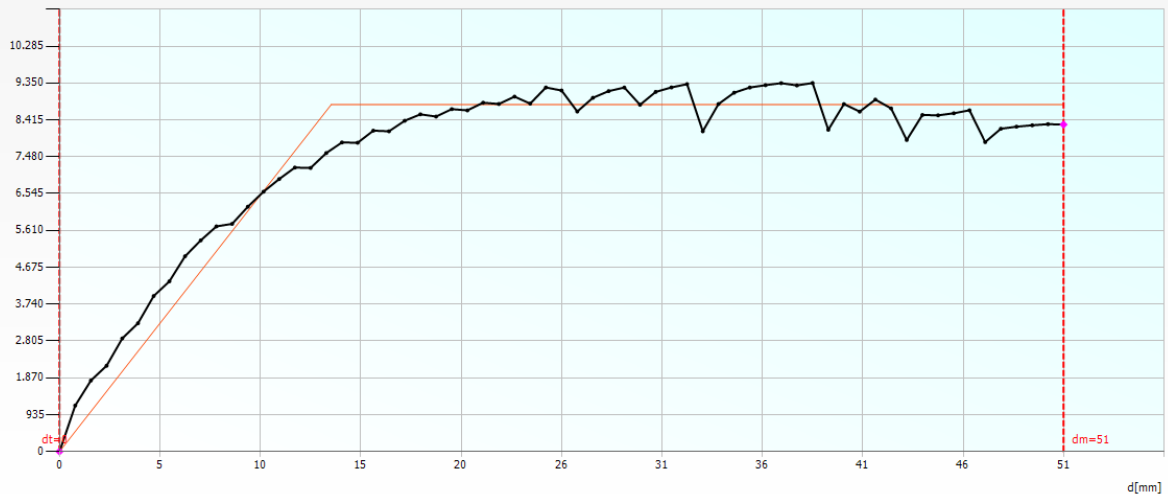

Figure 25. The most relevant pushover curve for the x-direction.

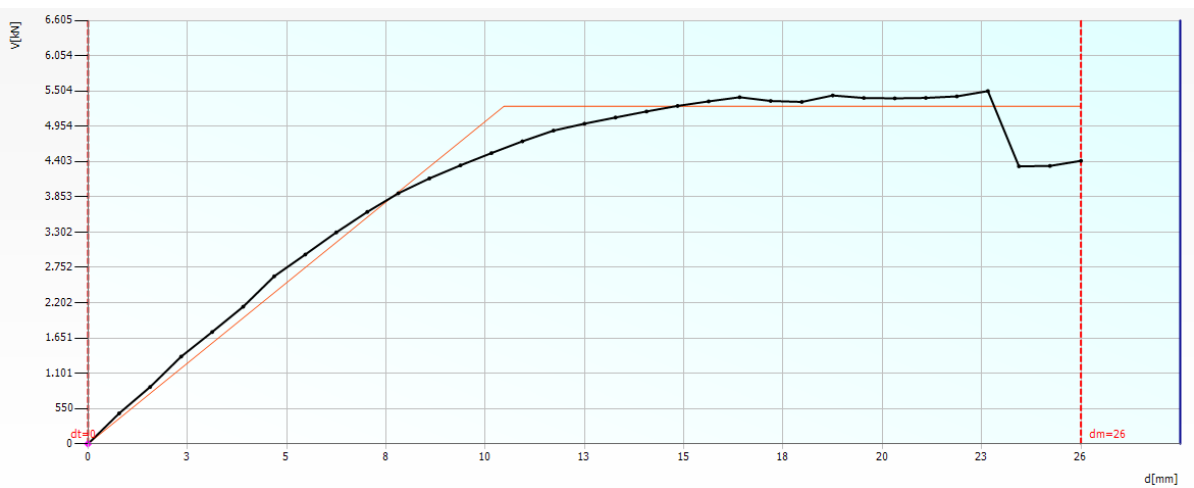

Figure 26. The most relevant pushover curve for the y-direction.

Figures 27 and 28 show the damaged state at the last step of the pushover curves for the $\mathrm{x}$ - and $\mathrm{y}$-direction where yellow color represents shear damage, and the red color represents bending damage.

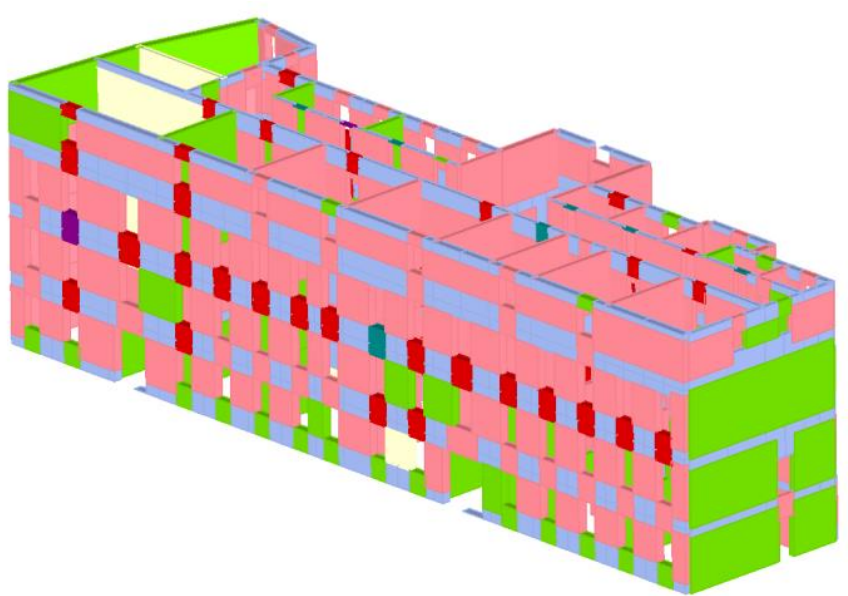

Figure 27. Damage at maximum displacement capacity for pushover in the x-direction. 


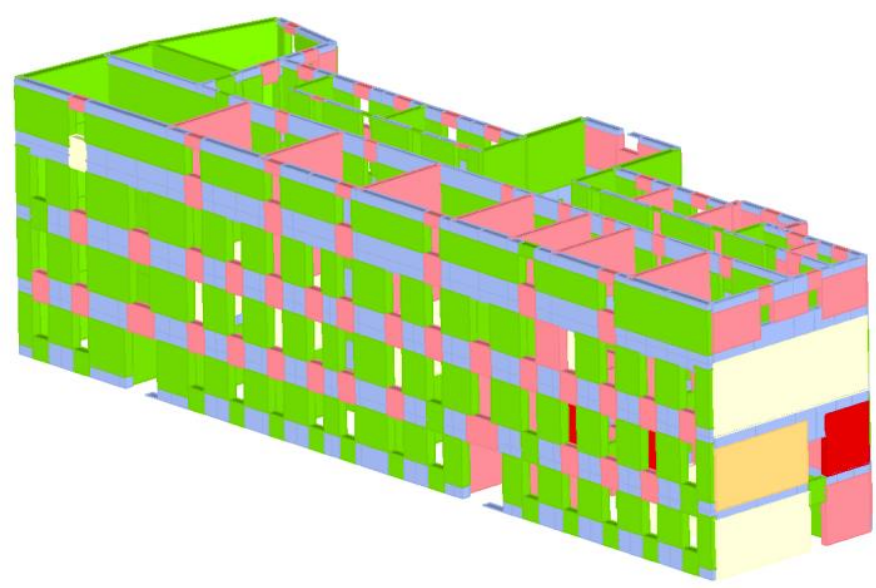

Figure 28. Damage at maximum displacement capacity for pushover in the y-direction.

After the response of the structure, the capacity of the structure is obtained and checks are carried out according to the basic requirements relating to the state of structural damage, defined by limit states. Parameters for equivalent SDOF systems from Figures 27 and 28 are shown in Table 3. These parameters are obtained during bilinearization based on the equivalent energy principal and are used for target displacement determination.

Table 3. SDOF parameters for pushover in $\mathrm{x}$ - and $\mathrm{y}$-direction.

\begin{tabular}{ccc}
\hline Parameter & Value (x-Direction) & Value (y-Direction) \\
\hline $\mathrm{T}^{*}(\mathrm{~s})$ & 0.411 & 0.433 \\
$\mathrm{~m}^{*}(\mathrm{~kg})$ & $2,725,590$ & $2,339,506$ \\
$\mathrm{w}(\mathrm{kN})$ & 45,733 & 45,733 \\
$\mathrm{M}(\mathrm{kg})$ & $4,661,901$ & $4,661,901$ \\
$\mathrm{~m}^{*} / \mathrm{M}(\%)$ & 58.47 & 50.18 \\
$\Gamma$ & 1.31 & 1.41 \\
$\mathrm{~F}^{*} \mathrm{y}(\mathrm{kN})$ & 6719 & 3736 \\
$\mathrm{~d}^{*} \mathrm{y}(\mathrm{cm})$ & 1.06 & 0.76 \\
$\mathrm{~d}^{*} \mathrm{~m}(\mathrm{~cm})$ & 3.91 & 1.81 \\
\hline
\end{tabular}

Results are also given in the form of a parameter $\alpha$ (Table 4), where $\alpha$ is the ratio between the limit capacity acceleration of the building and reference peak ground acceleration on type A ground. Parameter $\alpha$ is given for all limit states. A problem arises with old masonry buildings that often cannot be strengthened to such an extent that today's building codes regarding seismic resistance are satisfied. Hence, a new legal document [54] that followed recent earthquakes allows for different levels of earthquake resistance after reconstruction.

Table 4. $\alpha$ values.

\begin{tabular}{ccc}
\hline Return Period & $\alpha(x$-Direction $)$ & $\alpha$ (y-Direction) \\
\hline 475 & 0.633 & 0.291 \\
225 & 0.894 & 0.411 \\
95 & 0.560 & 0.363 \\
\hline
\end{tabular}

For the return period of 475 years, none of the 24 analyses satisfies the limit state of significant damage, while for the return period of 225 years, only 8 of the 24 analyses satisfies the same limit state. For a return period of 95 years, none of the 24 analyses satisfies the limit state of limited damage.

The target displacement is determined in accordance with Eurocode 8 (Appendix B) [52]. Since the building's natural period of vibration is less than the period of $T_{C}$, the target 
displacement is determined by the procedure for short periods shown in Figure 29. Buildings with short natural periods of vibration do not comply with the equal displacement rule [56] as buildings with medium-long and long natural periods of vibration.

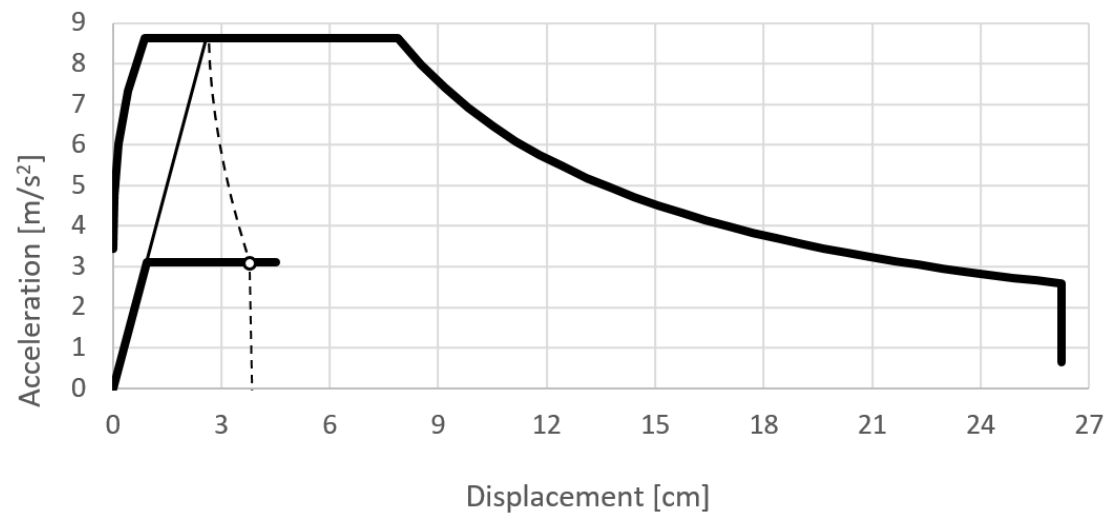

Figure 29. Target displacement determination for short periods.

Since 3Muri does not consider the bending failure of walls out-of-plane during the global non-linear static analysis, it is necessary to subsequently perform an analysis of the bending of the walls out-of-plane. This takes into account the seismic action perpendicular to the walls. The analysis is performed for the boundary condition near collapse. A return period of 475 years is used. Walls are considered to have passed the out-of-plane bending check if their $\mathrm{M}_{\mathrm{Rd}} / \mathrm{M}_{\mathrm{Ed}}$ ratio is greater than or equal to 1.0. In Figure 30, walls that did not satisfy the check are colored red.

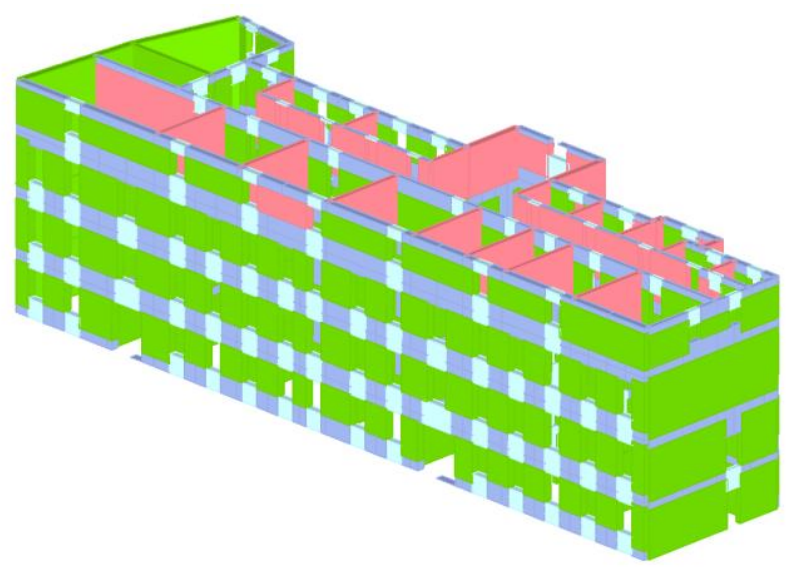

Figure 30. Bending out-of-plane results.

The 3Muri program does not consider out-of-plane loss of stability of local mechanisms in the global analysis either. It assumes that proper connection is established between walls and between walls and diaphragms. That way, out-of-plane local mechanisms are prevented so that the global in-plane response of the building can be evaluated [43]. Therefore, the resistance to local losses of stability is checked in a special program module; certain parts of a single wall are checked and the interaction of parts of several individual walls that can together form different local mechanisms. Figure 31 shows an example of a local mechanism where the kinematic block is colored red.

Local mechanisms are arbitrarily defined according to the structure's shape, common failure mechanisms and earthquake damage. The emergence of local mechanisms is often due to the poor interconnection of walls and walls with floor structures. Linear kinematic analysis is used. Defining a local mechanism consists of three steps. To begin with, it is necessary to define a kinematic block that is a part of a wall that is considered absolutely 
rigid, and that is subject to movement or tilting relative to another block or the rest of the wall. Then, the boundary conditions are defined and finally, the load needs to be set. Some of the possible local failure mechanisms of the observed structure and its resistance to the shown forms of failure are presented below (Figure 32 and Table 5). Parameter $\alpha$ represents the ratio between the spectral acceleration of the activation of the mechanisms and spectral acceleration of the seismic demand.

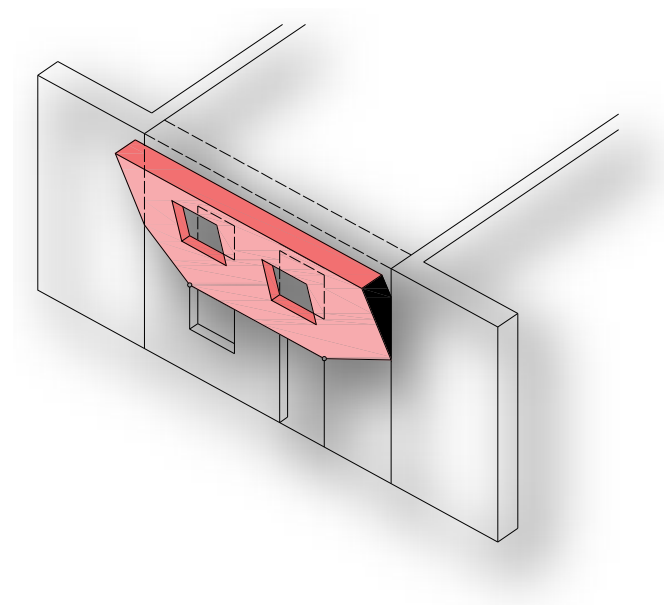

Figure 31. Example of a local mechanism.
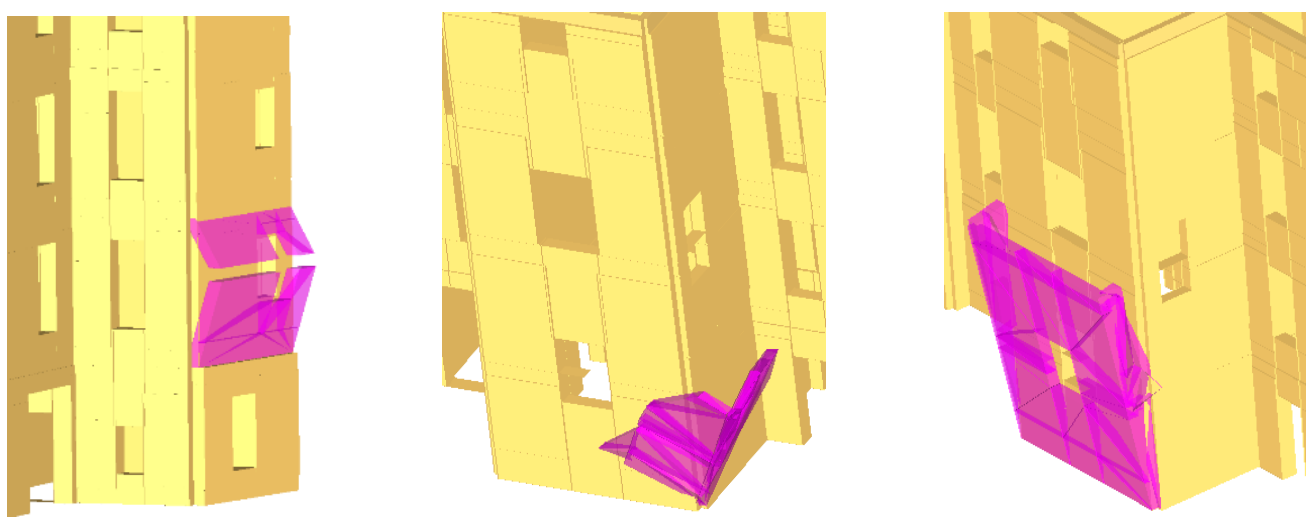

Figure 32. Local mechanism LM1 (east wing), LM2 and LM3 (central wing).

Table 5. Results for local mechanisms' analysis.

\begin{tabular}{cc}
\hline Local Mechanism & $\alpha$ \\
\hline LM1 & 4.93 \\
LM2 & 2.10 \\
LM3 & 0.53 \\
\hline
\end{tabular}

After the performed analyses, the real damage was compared with the damage distribution previewed in 3Muri (Figures 33-36). Description of building's capacity through displacement rather than forces allows us to better understand and accurately predict a building's response in the form of a damage initiation and propagation throughout all phases of analysis all the way until the formation of failure mechanism and collapse. That is possible, thanks to incremental non-linear static pushover analysis that shows us damage patterns for every macro-element in every step of the analysis. Compared results are very similar to real damage, which implies good accuracy of the used analysis and software. 


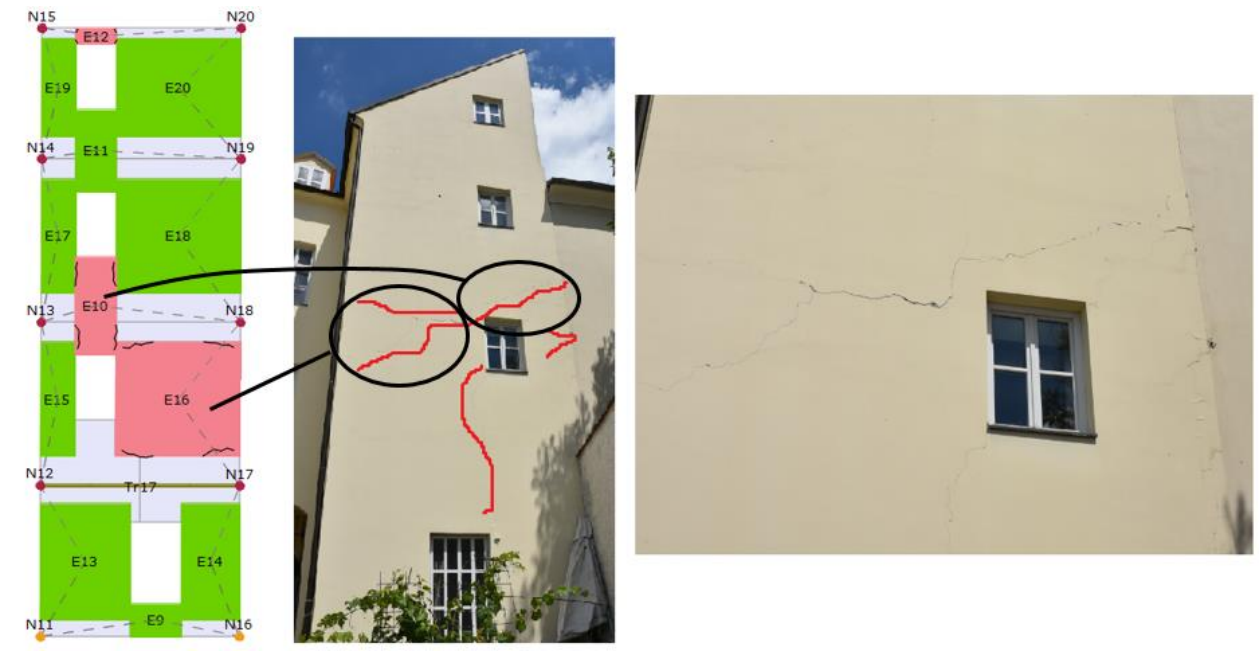

Figure 33. First comparison (photo credit: T. Kišiček).
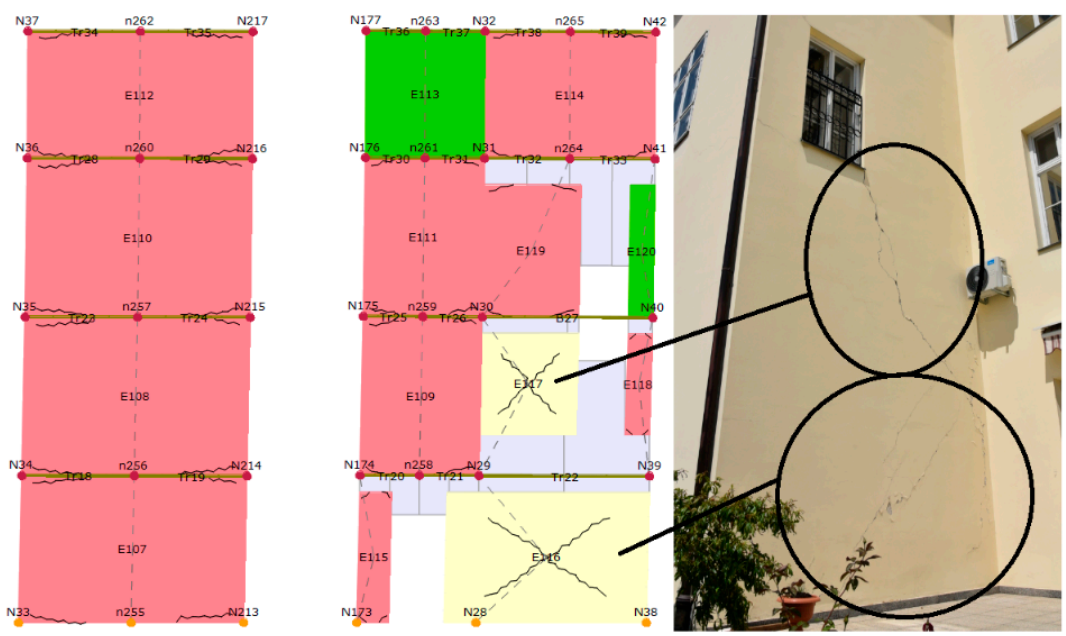

Figure 34. Second comparison (photo credit: T. Kišiček).

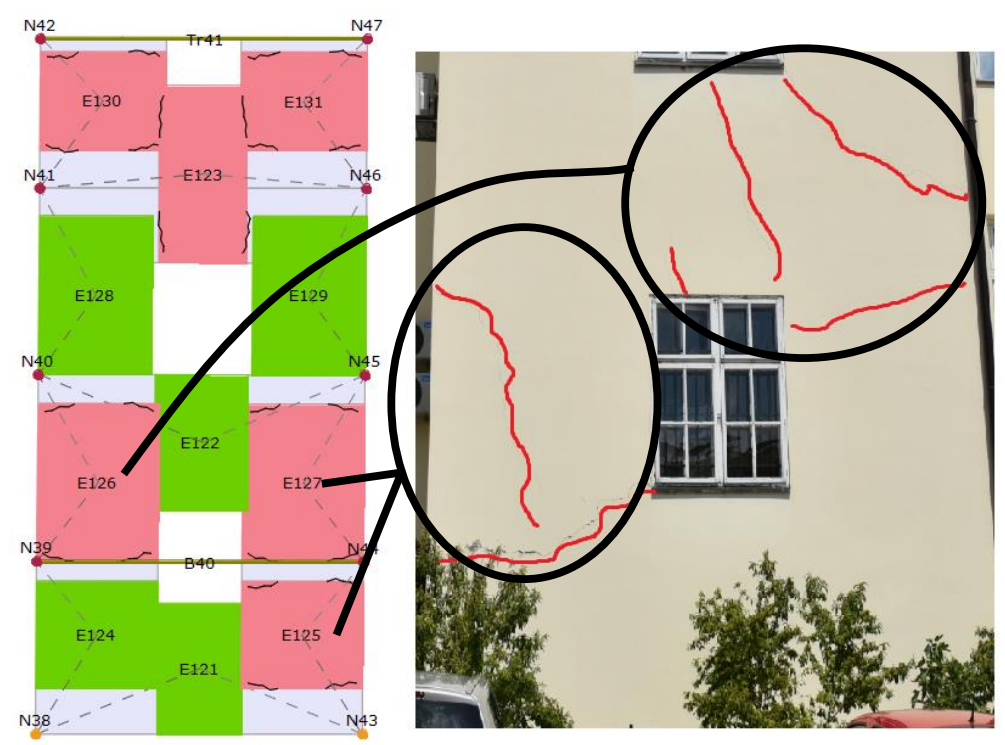

Figure 35. Third comparison (photo credit: T. Kišiček). 


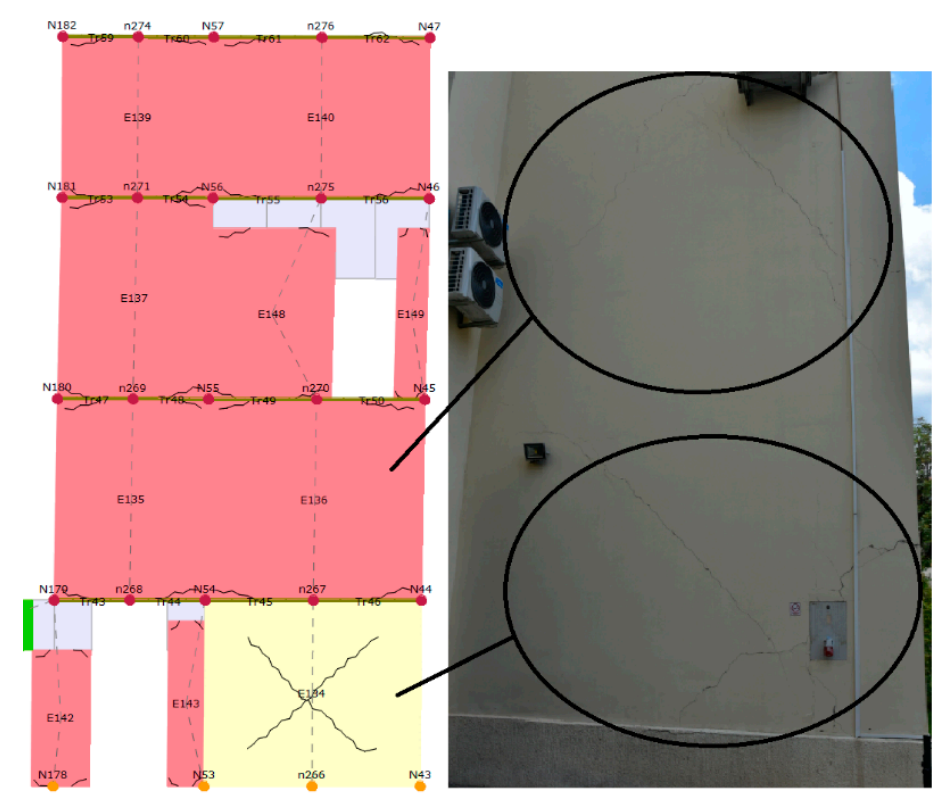

Figure 36. Fourth comparison (photo credit: T. Kišiček).

Another important piece of information is that the studied building is a part of a masonry building aggregate, which is not rare in Zagreb and other European cities. The behavior of buildings in the aggregate is extremely complex, where many parameters affect their response during an earthquake. Moreover, buildings at the ends of aggregates are often more severely damaged than those inside aggregates during earthquakes [57,58]. Modeling of the entire aggregate or, at least, adjacent buildings is recommended. Adjacent buildings can be modeled as mutually independent, mutually interconnected by the same walls, or mutually interconnected by various connections that accurately simulate real coherence. Those connections transfer axial and/or shear load between adjacent buildings in aggregate and they can be modeled as linear or non-linear elements [58-60]. Due to the lack of data on neighboring buildings, modeling of only the observed building is often resorted to. This is on the safe side in the case of a unit inside the aggregate when deformations are observed, but there is a risk of misinterpretation of the failure mechanism [61].

The observed building was modeled as an isolated unit due to insufficient data on neighboring buildings. In order to roughly assess the effect of neighboring buildings on the observed building, the vulnerability index proposed in the articles [62,63] is used. The index is based on five categories depending on the height of the surrounding buildings, the position of the building in the unit, the mismatch of floor heights, differences in material characteristics between buildings and differences in the areas of openings on the facade walls. This method was developed as an upgrade to the vulnerability index based on the ten parameters described in [64]. According to the mentioned five parameters, the buildings in the aggregate have a minimal impact on the observed building, and it can be assumed that the modeling of the building is as isolated as on the safe side.

\section{Discussion and Conclusions}

Based on similar case studies from the recent earthquakes in Italy [37,38,65-69], the assessment of the existing educational building is made in order to determine its seismic resistance. The building was damaged in the recent earthquakes in Croatia. The building was not constructed according to the principles of seismic design, but the reconstruction in 1997 partially improved the condition of the structure by adding transverse walls and replacing old wooden beams with reinforced concrete floors. Such rigid diaphragms enable good connection of all walls and thus, better behavior of the building in an earthquake. That is why increasing the stiffness of the traditional timber floors in old masonry buildings 
is usually one of the first measures in seismic retrofitting. On the other hand, new research suggests that replacing traditional wooden floors with rigid diaphragms, i.e., RC floors, can induce some unwanted consequences such as cracks on the edges of the two materials or, in the worst scenario, disintegration and collapse of the masonry walls. However, for earthquakes with expected smaller magnitudes as the ones in Zagreb, this measure is convenient and serves to reinforce the existing structure to horizontal actions.

The assessment of the existing unconfined masonry structure was performed using 3Muri with an equivalent frame method. Rather than linear analysis, non-linear static (pushover) seismic analysis is used due to its various benefits. Limit state checks were carried out for the return periods of 95, 225 and 475 years. The results are in line with the expected behavior with respect to the existing wall distribution in the structure. The structure is less rigid and has greater displacements in the y-direction. Additionally, the capacity of the structure is smaller for the y-direction. There is also a small eccentricity between the center of rigidity and the center of mass that causes a slight but negative impact of torsion on the global behavior of the structure. The critical elements are the walls of the central stairwell and the transverse walls on the west side of the building. Additionally, bending failure out-of-plane was checked. Local failure mechanisms were also analyzed using linear kinematic analysis. A comparison of the actual damage with the damage obtained as a result of the conducted non-linear static seismic analysis in the 3Muri program was also conducted.

After assessing the building's behavior in an earthquake, it is obvious that strengthening is needed to raise the seismic resistance level of the building. Damage caused by an earthquake must be repaired to prevent the progression of damage and the possible threat to the global resistance and stability of the building.

As Croatia was hit by two severe earthquakes last year, the knowledge of 'build back better' is fully appreciated. That means that sustainable materials and innovative concepts [70-73] should be used and energy efficiency ensured [74,75]. Various methods are used for strengthening of masonry buildings [76-78] and materials such as FRP and TRM will probably be adopted due to their compatibility and reversibility.

This study provides a detailed insight into the behavior of the building during the earthquake, as well as the extent and distribution of damage and critical elements for earthquakes of different intensities.

Author Contributions: Conceptualization: M.S., L.L. and T.K.; methodology: M.S. and T.K.; software: L.L.; validation: M.S. and T.K.; investigation: I.H., L.L. and K.O.; writing-original draft preparation: M.S., K.O., L.L. and I.H.; writing-review and editing: L.L., M.S. and T.K.; visualization: L.L., K.O., I.H. and M.S.; supervision: M.S. and T.K.; project administration: M.S. All authors have read and agreed to the published version of the manuscript.

Funding: This research was funded by the Croatian Science Foundation, grant number UIP-2019-043749 (ARES project-Assessment and rehabilitation of existing structures-development of contemporary methods for masonry and timber structures), project leader: Mislav Stepinac.

Institutional Review Board Statement: Not applicable.

Informed Consent Statement: Not applicable.

Data Availability Statement: The data presented in this study are available on request from the corresponding author. The data are not publicly available due to privacy reasons.

Conflicts of Interest: The authors declare no conflict of interest.

\section{References and Note}

1. Stepinac, M.; Lourenço, P.B.; Atalić, J.; Kišiček, T.; Uroš, M.; Baniček, M.; Šavor Novak, M. Damage classification of residential buildings in historical downtown after the ML5.5 earthquake in Zagreb, Croatia in 2020. Int. J. Disaster Risk Reduct. 2021, 56, 102140. [CrossRef]

2. Federal Republic of Yugoslavia (FRY) Official Journal. Ordinance on Technical Standards for the Construction of High-Rise Buildings in Seismic Areas. No. 31/81, 49/82, 29/83, 20/88, 52/90, 1 February 2021. 
3. Federal Republic of Yugoslavia (FRY) Official Journal. Ordinance on Temporary Technical Regulations for Construction in Seismic Areas. No. 39/64, 1 February 2021.

4. ARES Project 1st Workshop. Available online: www.grad.hr/ares (accessed on 15 February 2021).

5. Atalić, J.; Šavor Novak, M.; Uroš, M. Seismic risk for Croatia: Overview of research activities and present assessments with guidelines for the future. Građevinar. 2019, 71, 923-947.

6. Stepinac, M.; Gašparović, M. A Review of Emerging Technologies for an Assessment of Safety and Seismic Vulnerability and Damage Detection of Existing Masonry Structures. Appl. Sci. 2020, 10, 5060. [CrossRef]

7. Ortega, J.; Vasconcelos, G.; Rodrigues, H.; Correia, M.; Ferreira, T.M.; Vicente, R. Use of post-earthquake damage data to calibrate, validate and compare two seismic vulnerability assessment methods for vernacular architecture. Int. J. Disaster Risk Reduct. 2019, 39, 101242. [CrossRef]

8. Rodríguez, A.S.; Rodríguez, B.R.; Rodríguez, M.S.; Sánchez, P.A. 9-Laser Scanning and Its Applications to Damage Detection and Monitoring in Masonry Structures. Woodhead Publishing Series in Civil and Structural Engineering, Long-term Performance and Durability of Masonry Structures; Ghiassi, B., Lourenço, P.B., Eds.; Woodhead Publishing, 2019; pp. 265-285. Available online: https://www.sciencedirect.com/science/article/pii/B9780081021101000091 (accessed on 15 February 2021).

9. Yavari, S.; Chang, S.E.; Elwood, K.J. Modeling post-earthquake functionality of regional health care facilities. Earthq. Spectra. 2010, 26, 869-892. [CrossRef]

10. Marshall, J.D.; Jaiswal, K.; Gould, N.; Turner, F.; Lizundia, B.; Barnes, J.C. Post-earthquake building safety inspection: Lessons from the canterbury, New Zealand, earthquakes. Earthq. Spectra. 2013, 29, 1091-1107. [CrossRef]

11. Didier, M.; Baumberger, S.; Tobler, R.; Esposito, S.; Ghosh, S.; Stojadinovic, B. Improving post-earthquake building safety evaluation using the 2015 Gorkha, Nepal, Earthquake rapid visual damage assessment data. Earthq. Spectra. 2017, 33, 415-438. [CrossRef]

12. Zhang, Y.; Burton, H.V.; Sun, H.; Shokrabadi, M. A machine learning framework for assessing post-earthquake structural safety. Struct. Saf. 2018, 72, 1-16. [CrossRef]

13. Kim, T.; Song, J.; Kwon, O.S. Pre- and post-earthquake regional loss assessment using deep learning. Earthq. Eng. Struct. Dyn. 2020, 49, 657-678. [CrossRef]

14. Naito, S.; Tomozawa, H.; Mori, Y.; Nagata, T.; Monma, N.; Nakamura, H.; Fujiwara, H.; Shoji, G. Building-damage detection method based on machine learning utilizing aerial photographs of the Kumamoto earthquake. Earthq. Spectra. 2020, 36, 1166-1187. [CrossRef]

15. Bialas, J.; Oommen, T.; Rebbapragada, U.; Levin, E. Object-based classification of earthquake damage from high-resolution optical imagery using machine learning. J. Appl. Remote Sens. 2016, 10, 036025. [CrossRef]

16. Republic of Croatia Ministry of Construction and Physical Planning. Proposal of the Long-Term Strategy for Mobilising Investment in the Renovation of the National Building Stock of the Republic of Croatia. 2014. Available online: https://mgipu. gov.hr/UserDocsImages//dokumenti/Engleska / /HR-Art4BuildingStrategy_en.pdf (accessed on 15 February 2021).

17. Papadimitriou, P.; Kapetanidis, V.; Karakonstantis, A.; Spingos, I.; Kassaras, I.; Sakkas, V.; Kouskouna, V.; Karatzetzou, A.; Pavlou, K.; Kaviris, G.; et al. First Results on the Mw=6.9 Samos Earthquake of 30 October 2020. Bull. Geol. Soc. Greece. 2020, 56, 251-279. [CrossRef]

18. Günaydin, M.; Atmaca, B.; Demir, S.; Altunişik, A.C.; Hüsem, M.; Adanur, S.; Ateş, Ş.; Angin, Z. Seismic damage assessment of masonry buildings in Elazığ and Malatya following the 2020 Elazı̆̆-Sivrice earthquake, Turkey. Bull. Earthq. Eng. 2021, 19, 2421-2456. [CrossRef]

19. Casapulla, C.; Argiento, L.U.; Maione, A. Seismic safety assessment of a masonry building according to Italian Guidelines on Cultural Heritage: Simplified mechanical-based approach and pushover analysis. Bull. Earthq. Eng. 2018, 16, $2809-2837$. [CrossRef]

20. Grillanda, N.; Valente, M.; Milani, G.; Chiozzi, A.; Tralli, A. Advanced numerical strategies for seismic assessment of historical masonry aggregates. Eng. Struct. 2020, 212, 110441. [CrossRef]

21. Valente, M.; Milani, G. Damage assessment and collapse investigation of three historical masonry palaces under seismic actions. Eng. Fail. Anal. 2019, 98, 10-37. [CrossRef]

22. Ortega, J.; Vasconcelos, G.; Rodrigues, H.; Correia, M. Assessment of the influence of horizontal diaphragms on the seismic performance of vernacular buildings. Bull. Earthq. Eng. 2018, 16, 3871-3904. [CrossRef]

23. Endo, Y.; Pelà, L.; Roca, P. Review of Different Pushover Analysis Methods Applied to Masonry Buildings and Comparison with Nonlinear Dynamic Analysis. J. Earthq. Eng. 2017, 21, 1234-1255. [CrossRef]

24. Herak, M.; Allegretti, I.; Herak, D.; Ivančić, I.; Kuk, V.; Marić, K.; Markušić, S.; Sović, I. Seismic Hazard Map of Croatia for a Return Periods of 95, 225 and 475 years. Available online: http:/ / seizkarta.gfz.hr/karta.php (accessed on 15 February 2021).

25. Uroš, M.; Šavor Novak, M.; Atalić, J.; Sigmund, Z.; Baniček, M.; Demšić, M.; Hak, S. Post-earthquake damage assessment of buildings-procedure for conducting building inspections. Gradjevinar 2020, 72, 1089-1115. [CrossRef]

26. Stepinac, M.; Rajčić, V.; Barbalić, J. Inspection and condition assessment of existing timber structures. Gradjevinar 2017, 69, 861-873. [CrossRef]

27. Dall'Asta, A.; Leoni, G.; Meschini, A.; Petrucci, E.; Zona, A. Integrated approach for seismic vulnerability analysis of historic massive defensive structures. J. Cult. Herit. 2019, 35, 86-98. [CrossRef] 
28. Betti, M.; Bonora, V.; Galano, L.; Pellis, E.; Tucci, G.; Vignoli, A. An Integrated Geometric and Material Survey for the Conservation of Heritage Masonry Structures. Heritage 2021, 4, 35. [CrossRef]

29. Stepinac, M.; Kisicek, T.; Renić, T.; Hafner, I.; Bedon, C. Methods for the assessment of critical properties in existing masonry structures under seismic loads-the ARES project. Appl. Sci. 2020, 10, 1576. [CrossRef]

30. The Database of Usability Classification, Croatian Centre of Earthquake Engineering (HCPI—Hrvatski Centar za Potresno Inženjerstvo), Faculty of Civil Engineering, University of Zagreb and The City of Zagreb. June 2020. Available online: https: //www.hcpi.hr/ (accessed on 15 February 2021).

31. Seismic and Geological Micro-Zoning of a Part of the City of Zagreb, Book 1-Seismic and Geological Micro-Zoning, Croatian Geological Institute, Zagreb. 2019. Available online: https:/ / www.hgi-cgs.hr/studija-seizmicka-i-geoloska-mikronizacija-dijelagrada-zagreba/ (accessed on 15 February 2021).

32. Krolo, J.; Damjanović, D.; Duvnjak, I.; Smrkić, M.F.; Bartolac, M.; Košćak, J. Methods for determining mechanical properties of walls. Gradjevinar 2021, 73, 127-140. [CrossRef]

33. Methods of Test for Masonry-Part 3: Determination of Initial Shear Strength. Available online: https://standards.iteh.ai/ catalog/standards/cen/bbead1e6-bd33-4a25-bc75-c023da989f65/en-1052-3-2002 (accessed on 15 February 2021).

34. Eurocode 8: Design of Structures for Earthquake Resistance-Part 3: Assessment and Retrofitting of Buildings. Available online: https:/ / www.phd.eng.br/wp-content/uploads/2014/07/en.1998.3.2005.pdf (accessed on 15 February 2021).

35. Mouyiannou, A.; Rota, M.; Penna, A.; Magenes, M. Identification of Suitable Limit States from Nonlinear Dynamic Analyses of Masonry Structures. J. Earthq. Eng. 2014, 18, 231-263. [CrossRef]

36. Lamego, P.; Lourenço, P.B.; Sousa, M.L.; Marques, R. Seismic vulnerability and risk analysis of the old building stock at urban scale: Application to a neighbourhood in Lisbon. Bull. Earthq. Eng. 2017, 15, 2901-2937. [CrossRef]

37. Formisano, A.; Marzo, A. Simplified and refined methods for seismic vulnerability assessment and retrofitting of an Italian cultural heritage masonry building. Comput. Struct. 2017, 180, 13-26. [CrossRef]

38. Malcata, M.; Ponte, M.; Tiberti, S.; Bento, R.; Milani, G. Failure analysis of a Portuguese cultural heritage masterpiece: Bonet building in Sintra. Eng. Fail. Anal. 2020, 115, 104636. [CrossRef]

39. Fajfar, P.; Fischinger, M. N2-a method for non-linear seismic analysis of regular buildings. In Proceedings of the 9th World conference in earthquake engineering, Tokyo-Kyoto, Japan, 2-9 August 1998; pp. 111-116.

40. Cerovečki, A.; Kraus, I.; Morić, D. N2 building design method. Gradjevinar 2018, 70, 509-518. [CrossRef]

41. 3muri User Manual 12.2.1. Available online: https:/ / www.3muri.com/en/brochures-and-manuals / (accessed on 11 January 2021).

42. Kišiček, T.; Stepinac, M.; Renić, T.; Hafner, I.; Lulić, L. Strengthening of masonry walls with FRP or TRM. Gradjevinar 2020, 72, 937-953. [CrossRef]

43. Lagomarsino, S.; Penna, A.; Galasco, A.; Cattari, S. TREMURI program: An equivalent frame model for the nonlinear seismic analysis of masonry buildings. Eng. Struct. 2013, 56, 1787-1799. [CrossRef]

44. Penna, A.; Lagomarsino, S.; Galasco, A. A nonlinear macroelement model for the seismic analysis of masonry buildings. Earthq. Eng. Struct. Dyn. 2014, 43, 159-179. [CrossRef]

45. Turnšek, V.; Čačovič, F. Some Experimental Results on the Strength of Brick Masonry Walls. Available online: http://www.hms. civil.uminho.pt/ibmac/1970/149.pdf (accessed on 8 February 2021).

46. Tomaževič, M. Shear resistance of masonry walls and Eurocode 6: Shear versus tensile strength of masonry. Mater. Struct. Mater. Constr. 2009, 42, 889-907. [CrossRef]

47. Borri, A.; Castori, G.; Corradi, M.; Speranzini, E. Shear behavior of unreinforced and reinforced masonry panels subjected to in situ diagonal compression tests. Constr. Build. Mater. 2011, 25, 4403-4414. [CrossRef]

48. Borri, A.; Corradi, M.; Castori, G.; De Maria, A. A method for the analysis and classification of historic masonry. Bull. Earthq. Eng. 2015, 13, 2647-2665. [CrossRef]

49. Borri, A.; Corradi, A.; De Maria, A.; Sisti, R. Calibration of a visual method for the analysis of the mechanical properties of historic masonry. Procedia Struct. Integr. 2018, 11, 418-427. [CrossRef]

50. Borri, A.; Corradi, M.; De Maria, A. The Failure of Masonry Walls by Disaggregation and the Masonry Quality Index. Heritage 2020, 3, 65. [CrossRef]

51. Ghiassi, B.; Vermelfoort, A.T.; Lourenço, P.B. Masonry Mechanical Properties; Ghiassi, B., Milani, G., Eds.; Woodhead Publishing, 2019. Chapter 7. pp. 239-261. Available online: https://www.sciencedirect.com/science/article/pii/B9780081024393000075 (accessed on 8 February 2021). [CrossRef]

52. Eurocode 8: Design of Structures for Earthquake Resistance-Part 1: General Rules, Seismic Actions and Rules for Buildings. Available online: https:/ / www.phd.eng.br/wp-content/uploads/2015/02/en.1998.1.2004.pdf (accessed on 8 February 2021).

53. Eurocode 6: Design of Masonry Structures-Part 1-1: General Rules for Reinforced and Unreinforced Masonry Structures. Available online: https://www.phd.eng.br/wp-content/uploads/2015/02/en.1996.1.1.2005.pdf (accessed on 8 February 2021).

54. Law on the Reconstruction of Earthquake-Damaged Buildings in the City of Zagreb, Krapina-Zagorje County and Zagreb County (NN 102/2020). Available online: https://www.zakon.hr/z/2656/Zakon-o-obnovi-zgrada-o\%C5\%A1te\%C4\%87enih-potresomna-podru\%C4\%8Dju-Grada-Zagreba,-Krapinsko-zagorske-\%C5\%BEupanije,-Zagreba\%C4\%8Dke-\%C5\%BEupanije,-Sisa\%C4 \%8Dko-moslava\%C4\%8Dke-\%C5\%BEupanije-i-Karlova\%C4\%8Dke-\%C5\%BEupanije (accessed on 9 February 2021).

55. Eurocode 8: Design of Structures for Earthquake Resistance-Part 3: Assessment and Retrofitting of Buildings—National Annex. 
56. Sürmeli, M.; Yüksel, E. An adaptive modal pushover analysis procedure (VMPA-A) for buildings subjected to bi-directional ground motions. Bull. Earthq. Eng. 2018, 16, 5257-5277. [CrossRef]

57. Fagundes, C.; Bento, R.; Cattari, S. On the seismic response of buildings in aggregate: Analysis of a typical masonry building from Azores. Structures 2017, 10, 184-196. [CrossRef]

58. Senaldi, I.; Magenes, G.; Penna, A. Numerical Investigations on the Seismic Response of Masonry Building Aggregates. Adv. Mater. Res. 2010, 133-134, 715-720. [CrossRef]

59. Formisano, A.; Massimilla, A. A Novel Procedure for Simplified Nonlinear Numerical Modeling of Structural Units in Masonry Aggregates. Int. J. Archit. Herit. 2018, 12, 1162-1170. [CrossRef]

60. Stavroulaki, M.E. Dynamic Behavior of Aggregated Buildings With Different Floor Systems and Their Finite Element Modeling. Front. Built Environ. 2019, 5, 138. [CrossRef]

61. Tomić, I.; Penna, A.; DeJong, M.; Butenweg, C.; Correia, A.; Candeias, P.; Senaldi, I.; Guerrini, G.; Malomo, D.; Beyer, K. Seismic Testing of Adjacent Interacting Masonry Structures (AIMS). In Proceedings of the 17th World Conference on Earthquake Engineering, Sendai, Japan, 27 September-2 October 2021.

62. Formisano, A.; Landolfo, R.; Mazzolani, F.M.; Florio, G. A Quick Methodology for Seismic Vulnerability Assessment of Historical Masonry Aggregates. 2010. Available online: https://www.researchgate.net/publication/266617700_A_quick_methodology_ for_seismic_vulnerability_assessment_of_historical_masonry_aggregates (accessed on 8 February 2021).

63. Formisano, A.; Florio, G.; Landolfo, R.; Mazzolani, F.M. Numerical calibration of an easy method for seismic behaviour assessment on large scale of masonry building aggregates. Adv. Eng. Softw. 2015, 80, 116-138. [CrossRef]

64. Benedetti, D.; Benzoni, G.; Parisi, M.A. Seismic vulnerability and risk evaluation for old urban nuclei. Earthq. Eng. Struct. Dyn. 1988, 16, 183-201. [CrossRef]

65. Formisano, A. Theoretical and Numerical Seismic Analysis of Masonry Building Aggregates: Case Studies in San Pio Delle Camere (L'Aquila, Italy). J. Earthq. Eng. 2017, 21, 227-245. [CrossRef]

66. da Porto, F.; Munari, M.; Prota, A.; Modena, C. Analysis and repair of clustered buildings: Case study of a block in the historic city centre of L'Aquila (Central Italy). Constr. Build. Mater. 2013, 38, 1221-1237. [CrossRef]

67. Lucibello, G.; Brandonisio, G.; Mele, E.; De Luca, A. Seismic damage and performance of Palazzo Centi after L'Aquila earthquake: A paradigmatic case study of effectiveness of mechanical steel ties. Eng. Fail. Anal. 2013, 34, 407-430. [CrossRef]

68. Chieffo, N.; Formisano, A. Comparative Seismic Assessment Methods for Masonry Building Aggregates: A. Case Study. Front. Built Environ. 2019, 5, 123. [CrossRef]

69. Boschi, S.; Borghini, A.; Pintucchi, B.; Bento, R.; Milani, G. Seismic vulnerability of historic masonry buildings: A case study in the center of Lucca. Procedia Struct. Integr. 2018, 11, 169-176. [CrossRef]

70. Fortunato, G.; Funari, M.F.; Lonetti, P. Survey and seismic vulnerability assessment of the Baptistery of San Giovanni in Tumba (Italy). J. Cult. Herit. 2017, 26, 64-78. [CrossRef]

71. Stepinac, M.; Šušteršič, I.; Gavrić, I.; Rajcic, V. Seismic design of timber buildings: Highlighted challenges and future trends. Appl. Sci. 2020, 10, 1380. [CrossRef]

72. Funari, M.F.; Mehrotra, A.; Lourenço, P.B. A Tool for the Rapid Seismic Assessment of Historic Masonry Structures Based on Limit Analysis Optimisation and Rocking Dynamics. Appl. Sci. 2021, 11, 942. [CrossRef]

73. Funari, M.F.; Spadea, S.; Lonetti, P.; Fabbrocino, F.; Luciano, R. Visual programming for structural assessment of out-of-plane mechanisms in historic masonry structures. J. Build. Eng. 2020, 31, 101425. [CrossRef]

74. Milovanović, B.; Bagarić, M. How to achieve Nearly zero-energy buildings standard. Gradjevinar 2020, 72, 703-720. [CrossRef]

75. Valluzzi, M.R.; Salvalaggio, M.; Croatto, G.; Dorigatti, G.; Turrini, U. Nested Buildings: An Innovative Strategy for the Integrated Seismic and Energy Retrofit of Existing Masonry Buildings with CLT Panels. Sustainability 2021, 13, 1188. [CrossRef]

76. Ortega, J.; Vasconcelos, G.; Rodrigues, H.; Correia, M.; Lourenço, P.B. Traditional earthquake resistant techniques for vernacular architecture and local seismic cultures: A literature review. J. Cult. Herit. 2017, 27, 181-196. [CrossRef]

77. Skejić, D.; Lukačević, I.; Ćurković, I.; Čudina, I. Application of steel in refurbishment of earthquake-prone buildings. Gradjevinar 2020, 72, 955-966. [CrossRef]

78. Kouris, L.A.S.; Triantafillou, T.C. State-of-the-art on strengthening of masonry structures with textile reinforced mortar (TRM). Constr. Build. Mater. 2018, 188, 1221-1233. [CrossRef] 